\title{
Evaluation of tropospheric ozone and ozone precursors in simulations from the HTAPII and CCMI model intercomparisons - a focus on the Indian subcontinent
}

\author{
Zainab Q. Hakim ${ }^{1}$, Scott Archer-Nicholls ${ }^{1}$, Gufran Beig ${ }^{6}$, Gerd A. Folberth ${ }^{3}$, Kengo Sudo $^{4,5}$, Nathan \\ Luke Abraham $^{1,2}$, Sachin Ghude ${ }^{6}$, Daven K. Henze ${ }^{7}$, and Alexander T. Archibald ${ }^{1,2}$ \\ ${ }^{1}$ Department of Chemistry, University of Cambridge, Cambridge, UK \\ ${ }^{2}$ National Centre for Atmospheric Science, Cambridge, UK \\ ${ }^{3}$ UK Met Office Hadley Centre, Exeter, UK \\ ${ }^{4}$ Graduate School of Environmental Studies, Nagoya University, Nagoya, Japan \\ ${ }^{5}$ Japan Agency for Marine-Earth Science and Technology (JAMSTEC), Yokohama, Japan \\ ${ }^{6}$ Indian Institute of Tropical Meteorology, Pune, India \\ ${ }^{7}$ Department of Mechanical Engineering, University of Colorado, Boulder, CO, USA
}

Correspondence: Alexander T. Archibald (ata27@cam.ac.uk)

Received: 26 November 2018 - Discussion started: 7 December 2018

Revised: 26 March 2019 - Accepted: 29 March 2019 - Published: 16 May 2019

\begin{abstract}
Here we present results from an evaluation of model simulations from the International Hemispheric Transport of Air Pollution Phase II (HTAPII) and Chemistry Climate Model Initiative (CCMI) model inter-comparison projects against a comprehensive series of ground-based, aircraft and satellite observations of ozone mixing ratios made at various locations across India. The study focuses on the recent past (observations from 2008 to 2013, models from 2009-2010) as this is most pertinent to understanding the health impacts of ozone. To our understanding this is the most comprehensive evaluation of these models' simulations of ozone across the Indian subcontinent to date. This study highlights some significant successes and challenges that the models face in representing the oxidative chemistry of the region.

The multi-model range in area-weighted surface ozone over the Indian subcontinent is $37.26-56.11 \mathrm{ppb}$, whilst the population-weighted range is $41.38-57.5 \mathrm{ppb}$. When compared against surface observations from the Modelling Atmospheric Pollution and Networking (MAPAN) network of eight semi-urban monitoring sites spread across India, we find that the models tend to simulate higher ozone than that which is observed. However, observations of $\mathrm{NO}_{x}$ and $\mathrm{CO}$ tend to be much higher than modelled mixing ratios, suggesting that the underlying emissions used in the models do
\end{abstract}

not characterise these regions accurately and/or that the resolution of the models is not adequate to simulate the photochemical environment of these surface observations. Empirical orthogonal function (EOF) analysis is used in order to identify the extent to which the models agree with regards to the spatio-temporal distribution of the tropospheric ozone column, derived using OMI-MLS observations. We show that whilst the models agree with the spatial pattern of the first EOF of observed tropospheric ozone column, most of the models simulate a peak in the first EOF seasonal cycle represented by principle component 1 , which is later than the observed peak. This suggests a widespread systematic bias in the timing of emissions or some other unknown seasonal process.

In addition to evaluating modelled ozone mixing ratios, we explore modelled emissions of $\mathrm{NO}_{x}, \mathrm{CO}$, volatile organic compounds (VOCs) and the ozone response to the emissions. We find a high degree of variation in emissions from non-anthropogenic sources (e.g. lightning $\mathrm{NO}_{x}$ and biomass burning $\mathrm{CO}$ ) between models. Total emissions of $\mathrm{NO}_{x}$ and $\mathrm{CO}$ over India vary more between different models in the same model intercomparison project (MIP) than the same model used in different MIPs, making it impossible to diagnose whether differences in modelled ozone are due to emissions or model processes. We therefore recommend targeted 
experiments to pinpoint the exact causes of discrepancies between modelled and observed ozone and ozone precursors for this region. To this end, a higher density of long-term monitoring sites measuring not only ozone but also ozone precursors including speciated VOCs, located in more rural regions of the Indian subcontinent, would enable improvements in assessing the biases in models run at the resolution found in HTAPII and CCMI.

\section{Introduction}

The issues of increasing levels of surface ozone $\left(\mathrm{O}_{3}\right)$ and its impacts on human health, the biosphere and climate are of major concern globally. Recent reports from the Health Effects Institute (2017) highlight that ambient ozone contributes to the global health burden through its impact on premature deaths and disabilities from chronic obstructive pulmonary disease (COPD). Nearly 4.5 million people die prematurely each year due to exposure to outdoor pollution, 254000 of which are due to ozone exposure and its impact on chronic lung disease; the remaining majority are attributed to particulate matter below $2.5 \mu \mathrm{m}$ in diameter $\left(\mathrm{PM}_{2.5}\right)$. Around half of these premature deaths are in China and India Cohen et al. (2017). However, a recent study using updated risk estimates suggests that previous analyses have underestimated the long-term health impacts of tropospheric ozone, and the true global disease burden could be over 1 million premature deaths per year, 400000 of which occur in India (Malley et al., 2017). India and its neighbouring countries, China, Pakistan and Bangladesh, have experienced the largest increase in seasonal average population-weighted ozone concentrations over the last 25 years (Health Effects Institute, 2017), with India alone accounting for $67 \%$ of the global increase in ambient-ozone-attributable deaths due to COPD between 1990 and 2015.

The ill effects of ozone are not only limited to human health. Ghude et al. (2008) calculated relative agricultural yield loss using accumulated ozone exposure exceedances over a threshold of $40 \mathrm{ppb}$ from the analysis of 7 years of data of hourly surface ozone concentrations over India (19972004) during the pre-monsoon season. They estimated yield losses of $22.7 \%, 22.5 \%, 16.3 \%$ and $5.5 \%$ for wheat, cotton, soya bean and rice respectively, sufficient to feed about 94 million people and an economic value of more than a billion USD per year.

Identifying the sources and sinks of tropospheric ozone and its precursors, and in turn identifying the ways to reduce ambient ozone exposure, remains a key challenge. Ozone is a secondary pollutant, meaning it is not directly emitted into the atmosphere. The tropospheric chemistry of ozone and its precursor species, such as volatile organic compounds (VOCs), carbon monoxide (CO) and nitrogen oxides $\left(\mathrm{NO}_{x}=\mathrm{NO}+\mathrm{NO}_{2}\right)$, is complex and involves a large num- ber of species that participate in a cascade of $\mathrm{NO}_{x}$-catalysed chemical reactions that ultimately oxidise VOCs to $\mathrm{H}_{2} \mathrm{O}$ and $\mathrm{CO}_{2}$, generating ozone as a by-product (Jenkin and Clemitshaw, 2002; Monks et al., 2015). India is experiencing a rapid growth in its industrial and economic sectors with increasing emissions of pollutants and trace gases associated with this development (Ghude et al., 2008, 2013). An increasing trend in tropospheric ozone over most parts of India has been observed in long-term decadal trend analysis (1979-2000) using satellite-based approaches to determine the tropospheric ozone residual (TOR), with the strongest trends observed over the Indo-Gangetic Plain (The IGP region - a region to the north of India, at the foothills of Himalayas) (Lal et al., 2012).

Meteorological parameters also play an important role in driving tropospheric ozone chemistry, as has been demonstrated in many studies in the last few years. Central to the production of ozone is photolysis (photo-dissociation). The presence of clouds can greatly impact the rates of photolytic reactions and so act as a limit for ozone production (Voulgarakis et al., 2009). Ozone also tends to have a positive correlation with temperature and a negative correlation with relative humidity (Camalier et al., 2007). Increases in water vapour directly lead to ozone loss through the reaction of excited oxygen atoms, formed from ozone photolysis, with water, and indirectly through the wet scavenging of compounds which act as reservoirs and precursors for ozone (Monks et al., 2015). These meteorological factors are of particular importance for the Indian subcontinent, where the seasonal cycle is dominated by the monsoon season, lasting for 4 months from June to September and characterised by high precipitation rates, cloudy days, seasonal reversal of prevailing wind directions, and mixing of the clean marine boundary layer air from the south-west with the continental air. Ground-based studies on ozone cycles at various sites in India report that the minimum ozone values observed during the monsoon season are likely attributed to high relative humidity, low solar radiation, cloudiness conditions and wet scavenging of ozone precursors. In contrast, the high temperatures, high solar radiation and low humidity during the pre- and post-monsoon seasons provide favourable conditions for photochemical production of $\mathrm{O}_{3}$. During winter, low temperatures, low solar radiation and fog limits the photochemical $\mathrm{O}_{3}$ production in most parts of India (Beig et al., 2007; Sinha et al., 2015; Yadav et al., 2016). An exception is the Mt. Abu site in northern India. Due to the unique meteorology at this high altitude site, the seasonal variation in surface ozone shows a maximum in late autumn and winter (Naja et al., 2003).

Owing to the complex interplay between emissions, chemistry and the unique meteorology that impacts the Indian subcontinent, and the limited coverage of surface observations, three-dimensional numerical models are required to estimate the health burden of ozone exposure and predict how ozone levels will respond to future changes in emissions and climate. Three-dimensional numerical models include meteo- 
rology, emissions and complex photo-chemical mechanisms to simulate ozone concentrations (Keeble et al., 2017; Surendran et al., 2015). But these models need to be evaluated with as many observations of as many species that contribute to ozone production and loss as possible. The ability of a model to accurately predict the present state of species gives us the confidence to rely on them for future projections as well as to predict the levels of pollutants in regions where observations are limited. Many previous studies have evaluated the ability of chemistry-transport models to simulate levels of ozone and other key species for tropospheric chemistry over North America and Europe, where dense, long-term and reliable measurements are available (Im et al., 2015; O'Connor et al., 2014; Tilmes et al., 2015). Owing to the sparsity of in situ data, these kinds of studies are limited over the Indian subcontinent. Evaluation of models and their agreement as well as disagreement over this region will enhance our understanding about the production of ozone and the factors controlling it. An improvement in our fundamental ability to simulate the processes which control ozone will ultimately enable the best policy decisions to mitigate the impacts of ozone on human health and crops in the region.

In this paper, we have evaluated model simulations from the international Hemispheric Transport of Air Pollution Phase II (HTAPII) and Chemistry Climate Model Initiative (CCMI) model inter-comparison projects against a comprehensive series of ground-based, aircraft and satellite observations of ozone, $\mathrm{NO}_{x}$ and $\mathrm{CO}$ across India. To our knowledge, this represents the most exhaustive evaluation of ozone for these models in this region and enables us to characterise seasonal biases and errors between the models. Section 2 describes the models that we have used in these analyses and the observations we used to evaluate the models against. In Sect. 3 we present the results of our evaluation, including empirical orthogonal function (EOF) analysis to identify similarities and differences in the spatio-temporal distribution of the tropospheric ozone column simulated in the models and retrieved from the OMI-MLS instruments (Ziemke et al., 2011). In Sect. 4, we discuss the results and suggest possible future research needed to understand ozone chemistry over the Indian subcontinent.

\section{Methodology}

\subsection{Datasets for evaluation}

\subsubsection{Ground-based observations}

The model simulations have been validated against measurements of surface ozone from eight stations located across India in Delhi, Patiala, Udaipur, Jabalpur, Pune, Hyderabad, Guwahati and Chennai. Figure 4 shows the geographical locations of these stations. Details of all the ground-based stations have been summarised in Table 1 . The coordinated
Table 1. Details of the locations of in situ ozone monitoring stations used in this study. All stations are categorised as semi-urban sites. All data were collected at an hourly resolution throughout the year 2013. For more details see Sect. 2.1.1.

\begin{tabular}{lllrl}
\hline Stations & $\begin{array}{l}\text { Lat. } \\
\left({ }^{\circ} \mathrm{N}\right)\end{array}$ & $\begin{array}{l}\text { Long. } \\
\left({ }^{\circ} \mathrm{E}\right)\end{array}$ & $\begin{array}{r}\text { Elevation } \\
\text { (m a.s.1.) }\end{array}$ & Institutes \\
\hline Delhi & $28^{\circ} 41^{\prime}$ & $77^{\circ} 12^{\prime}$ & 253 & IMD, Lodhi Road \\
Patiala & $30^{\circ} 21^{\prime}$ & $76^{\circ} 22^{\prime}$ & 257 & Thapar University \\
Udaipur & $24^{\circ} 35^{\prime}$ & $73^{\circ} 43^{\prime}$ & 255 & M.L.S University \\
Jabalpur & $23^{\circ} 9^{\prime}$ & $79^{\circ} 58^{\prime}$ & 420 & Govt. Model \\
& & & & Science College \\
Pune & $18^{\circ} 32^{\prime}$ & $73^{\circ} 48^{\prime}$ & 590 & IITM, Pune \\
Hyderabad & $17^{\circ} 31^{\prime}$ & $78^{\circ} 24^{\prime}$ & 609 & INCOIS \\
Guwahati & $26^{\circ} 9^{\prime}$ & $91^{\circ} 39^{\prime}$ & 56 & Gauhati University \\
Chennai & $13^{\circ} 2^{\prime}$ & $80^{\circ} 8^{\prime}$ & 20 & Sri Ramchandra \\
& & & & University \\
\hline
\end{tabular}

measurements of trace gases and aerosols at these locations of India are carried out under the Indian Institute of Tropical Meteorology (IITM), Pune, India, and Ministry of Earth Sciences (MoES) as part of the "Modelling Atmospheric Pollution and Networking" (MAPAN) programme. The Lodhi Road station in Delhi is designated as being an urban background site. All other monitoring stations are designated as semi-urban, indicating that the stations are away from downtown areas where the influence of local emissions may be very high. However, as we show in Sect. 3, these are far from pristine measurement locations and appear to be influenced by high levels of $\mathrm{NO}_{x}$ and $\mathrm{CO}$. Observations at these stations were made with the Air Quality Management System (AQMS). The AQMS is comprised of US Environmental Protection Agency approved analysers housed inside walkway shelters and have a sampling height of $3 \mathrm{~m}$ above ground level (Beig et al., 2013).

The measurements of surface $\mathrm{O}_{3}, \mathrm{NO}_{x}$ and $\mathrm{CO}$ were made continuously at hourly time resolution during the year 2013. Ozone measurements were conducted using an Ecotech Ozone analyser (model number EC 9810B), which combines the benefits of microprocessor control with ultraviolet (UV) photometry at $254 \mathrm{~nm}$ to accurately measure ozone mixing ratios in ambient air. The analyzer provides accurate measurements of ozone in the range of 0-20 ppmv with a detection limit of $0.5 \mathrm{ppbv}$ and has a linearity error of less than $3 \%$.

The measurements of $\mathrm{NO}_{x}$ were made by using an Ecotech Nitrogen Oxides Analyzer (model number EC 9841B). This analyzer works on the chemiluminescence technique for accurate and reliable measurements of $\mathrm{NO}, \mathrm{NO}_{2}$ and $\mathrm{NO}_{x}$ mixing ratios. The technical limitations (artifacts) of the chemiluminescent-based methods have been well reported (Fuchs et al., 2009; Winer et al., 1974). CO was measured using an Ecotech model EC 9830 analyzer based on the infrared (IR) photometry. Information on the maintenance and calibration of these instruments has been reported before 
(Chakraborty et al., 2015; Yadav et al., 2014). Monthly mean values for $\mathrm{O}_{3}, \mathrm{NO}_{x}$ and $\mathrm{CO}$ were calculated from the $24 \mathrm{~h}$ averages of the hourly data. Days with fewer than $15 \mathrm{~h}$ of observations were excluded from the analysis.

\subsubsection{CARIBIC observations}

The CARIBIC project (Civil Aircraft for the Regular Investigation of the atmosphere Based on an Instrument Container; http://www.caribic-atmospheric.com/, last access: 4 April 2018) aims to investigate the spatial and temporal distribution of a wide-range of compounds. It is based on the use of a fully automated scientific instrument package in a $1.5 \mathrm{t}$ container aboard a passenger aircraft which is equipped with an advanced multi-probe inlet system (Brenninkmeijer et al., 2007). In the region of interest, flights operated monthly from April to December 2008 aboard a Lufthansa Airbus A340600 passenger aircraft flying from Frankfurt to Chennai. The total number of flights during this period was 16 . Usually one set of flights consisted of four consecutive flights, i.e. two round trips from Frankfurt to Chennai within 3 days, with the exception of July and October, when only one round trip was performed. The ascents and descents of the flights took place during night, with landing times around 23:30 local time and take off times around 02:00 and 03:40 local time the next morning (Ojha et al., 2016).

The ozone measurements were made by a dry chemiluminescence (CL) instrument, which at typical ozone mixing ratios between 10 and $100 \mathrm{ppb}$ and a measurement frequency of $10 \mathrm{~Hz}$ has a precision of $0.3 \%-1.0 \%$. The absolute ozone concentration is inferred from a UV photometer designed inhouse which operates at $0.25 \mathrm{~Hz}$ and reaches an accuracy of $0.5 \mathrm{ppb}$. The CL instrument has been discussed in detail by Zahn et al. (2012).

$\mathrm{CO}$ is measured with an AeroLaser AL 5002 resonance fluorescence UV instrument modified for use on board the CARIBIC passenger aircraft. The instrument has a precision of 1-2 ppbv at an integration time of $1 \mathrm{~s}$ and performs an inflight calibration every $25 \mathrm{~min}$. Technical details of the CO instrument can be found in Scharffe et al. (2012).

The CARIBIC observations taken during ascent as well as descent of the flight have been considered in this study. These observations are averaged into vertical bins of $25 \mathrm{hPa}$. For monthly mean vertical profiles, averages of all the ascending and descending profiles during that month have been considered. For comparison, monthly mean model-simulated profiles over Chennai are also averaged into vertical bins of $25 \mathrm{hPa}$ and have been interpolated to the CARIBIC pressure levels.

\subsubsection{OMI/MLS tropospheric column ozone (TCO) measurements}

Tropospheric column ozone (TCO) for the year 2010 is derived using the TOR method, which is the residual of total column ozone from the Ozone Measuring Instrument (OMI) and stratospheric column ozone from the Microwave Limb Sounder (MLS) with the spatial resolution of Aura/MLS (Ziemke et al., 2011; Schoebert et al. 2007). TOR is an integrative product which accounts for changes in ozone not only at the surface, where it is most detrimental to human and crop health, but also in the free troposphere, where it has a longer lifetime and so is influenced by more sources and has a larger climate impact (Stevenson et al., 2013).

OMI and MLS are two out of four instruments on board the Aura satellite, which orbits the Earth in sun-synchronous polar orbit at $705 \mathrm{~km}$ altitude and $98.2^{\circ}$ inclination. OMI is a nadir-viewing instrument which detects back-scattered solar radiance from Earth at visible $(350-500 \mathrm{~nm})$ and UV (270$314 \mathrm{~nm}, 306-380 \mathrm{~nm}$ ) wavelengths to measure total column ozone with a spatial resolution of $13 \mathrm{~km} \times 24 \mathrm{~km}$. The MLS instrument detects microwave thermal emissions from the limb of Earth's atmosphere to measure mesospheric, stratospheric and upper tropospheric temperature, ozone and other constituents. MLS measurements are taken about $7 \mathrm{~min}$ before OMI views the same location during ascending (daytime) orbital tracks. Details of these instruments are discussed elsewhere (Waters et al., 2006).

\subsection{Model description}

In this work we aim to evaluate how a range of models perform over the Indian subcontinent to understand what the level of agreement in ozone modelling is, in this observationally sparse region. We focus here on global models as these are increasingly used in assessments of the health impacts of air pollution (e.g. Malley et al., 2017; Lelieveld et al., 2018). There is a long history of coordinated model intercomparison projects (MIPs), with the general aim of coordinating modelling centres to better understand how the state-of-thescience models compare against each other and observations. MIPs are generally focused on specific science questions which define the length of the integrations performed with the models and the amount of model output requested. MIPs have been the key mechanism to bring together our understanding of climate change and are increasingly enabling our understanding of atmospheric composition to be improved.

The most recent global MIPs include both the CCMI (Morgenstern et al., 2017) and international HTAPII (Koffi et al., 2016). We opted to look at data from both of these MIPs but, owing to constraints on time and data availability, chose to focus on a subset of models. Specifically, we examine output from simulations from the following eight models:

- HadGEM2-ES model (Collins et al., 2011; Jones et al., 2011), hereafter referred to as HTAPII-HDGM;

- GEOS-Chem Adjoint (Henze et al., 2007), hereafter referred to as HTAPII-GCAD;

- CHASER-v4-MIROC-ESM and CHASER-MIROCESM (two different configurations of essentially the 


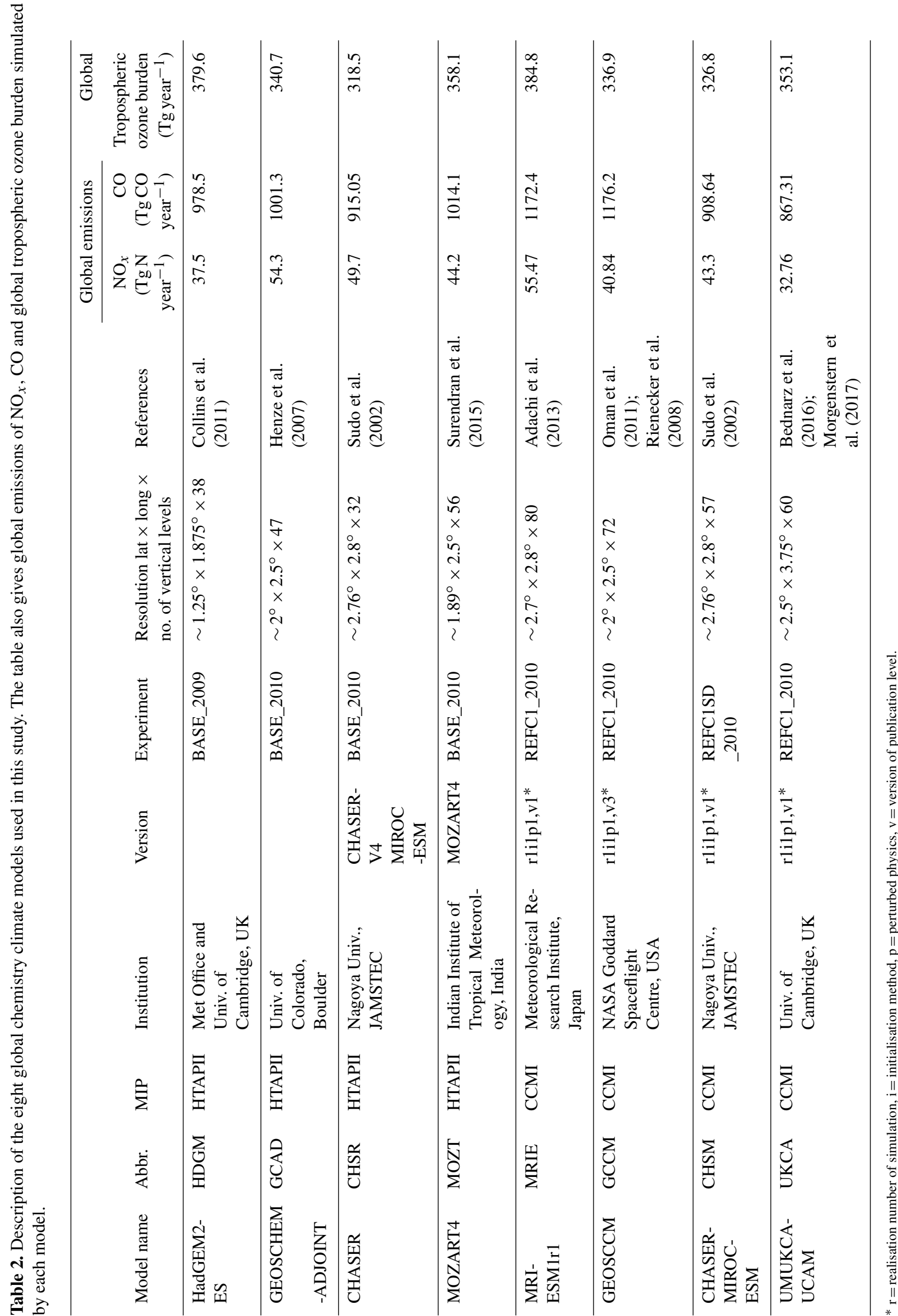


same model run for HTAPII and CCMI and referred to as HTAPII-CHSR and CCMI-CHSM respectively) (Sudo et al., 2002a, b);

- MOZART-4 (Divya et al., 2015), hereafter referred to as HTAPII-MOZT;

- MRI-ESM1r1 (Yukimoto et al., 2011; Deushi and Shibata 2011), hereafter referred to as CCMI-MRIE;

- GEOSCCM (Oman et al., 2011; Reinecker et al., 2008; Duncan et al., 2007; Strahan et al., 2007), hereafter referred to as CCMI-GCCM;

- UMUKCA-UCAM (Bednarz et al., 2016), hereafter referred to as CCMI-UKCA.

Table 2 outlines the details of the above models, with which the MIPs were run, and documents our calculations of the tropospheric ozone burden in each model (using a consistent treatment of a chemical tropopause defined using a $150 \mathrm{ppb}$ monthly mean ozone iso-surface). These models span a range of horizontal resolution (the lowest resolution is CCMI-UKCA at lat $2.5^{\circ} \times$ long $3.75^{\circ}$ and highest resolution is HTAPII-HDGM at $1.25^{\circ}$ lat $\times 1.85^{\circ}$ long) and vertical resolution (HTAPII-CHSR/CCMI-CHSM have 32 vertical model levels, whilst CCMI-MRIE has 80 vertical model levels) and use chemical mechanisms of differing complexity and scope (e.g. CCMI-UKCA has been designed for simulations of mainly stratospheric nature whilst HTAPII-CHSR and CCMI-CHSM use a chemistry scheme much more focused on tropospheric oxidation, with a larger number of non-methane VOCs). The lowest model level varies from a minimum of $25 \mathrm{~m}$ for CCMI-MRIE to $124 \mathrm{~m}$ for HTAPIIGCAD. For further details of the model set-ups please see the cited references for each model in Table 2 and the MIP description papers (i.e. for the CCMI models see Morgenstern et al., 2017). From our analysis of the tropospheric ozone burden, we see that all models lie within the range of the Atmospheric Chemistry and Climate Model Intercomparison Project (ACCMIP) models (Young et al., 2013) and the likely range as recently quantified through satellite retrievals of the tropospheric column analysed by the IGAC Tropospheric Ozone Assessment Report (TOAR) (Gaudel et al., 2018).

From the eight models described above, we focus our analysis on monthly and daily mean mixing ratios of ozone, $\mathrm{NO}_{x}$ and $\mathrm{CO}$, and monthly mean surface emissions of $\mathrm{CO}, \mathrm{NO}_{x}$ and lightning-derived $\mathrm{NO}_{x}$. We focus on output from the models appropriate for the year 2010 and limit the main analysis to the domain of $56-105^{\circ}$ longitude and 5-38 latitude, which covers the entire Indian subcontinent.

In spite of simulating the same period of time, CCMI and HTAPII use different base emission inventories as part of their protocol. Surface $\mathrm{CO}$ and $\mathrm{NO}_{x}$ emissions, which over the Indian subcontinent are dominated by anthropogenic sources, should generally be consistent within MIPs, which we largely see but explore in more detail below. Lightning is an important source of $\mathrm{NO}_{x}$ to the remote atmosphere. It is an emission term that tends to be not possible to specify in the MIPs, and hence it reflects an area of emissions that models should differ in. We assess this in more detail below.

\subsubsection{Description of emissions from model simulations}

The annual total $\mathrm{NO}_{x}$ and $\mathrm{CO}$ emissions for all models over the domain are shown in Figs. 1, S2 and S3. Briefly, there is large variability in input emissions of $\mathrm{NO}_{x}$ and $\mathrm{CO}$ for the different models and MIPs (Figs. S2 and S3). The intra-MIP variability is greater than the inter-MIP variability for $\mathrm{NO}_{x}$; i.e. there is more variability within a MIP for $\mathrm{NO}_{x}$ emissions than between them (see Fig. 1). However, the converse is true for $\mathrm{CO}$ where the CCMI emissions tend to be higher than those used in the HTAPII MIP. For individual MIPs, every modelling group was required to use the same anthropogenic emissions data. Disparities in emissions may be due to the use of different natural and biomass burning sources.

Lightning is the largest contributor to upper tropospheric $\mathrm{NO}_{x}$ and it is a source of largest uncertainty. Global emissions of lightning $\mathrm{NO}_{x}\left(\mathrm{LNO}_{x}\right)$ as simulated by the models show a variance of $7.56 \mathrm{Tg}(\mathrm{N})$ year $^{-1}$ (annual global emission of $\mathrm{LNO}_{x}$ as simulated by each model is given in Fig. 2). The vertical profiles of $\mathrm{LNO}_{x}$ emissions are very different in each model over the domain considered in this study (Fig. 2). Parameterisation of $\mathrm{LNO}_{x}$ is highly dependent on the vertical and horizontal resolution of the models. CCMI-UKCA and HTAPII-HDGM models show similar vertical profiles as they have a similar internal configuration. The difference in the convection parameterisation in these models leads to a difference in the magnitudes of $\mathrm{LNO}_{x}$ emissions. CCMIMRIE clearly stands out, giving the highest values of $\mathrm{LNO}_{x}$ emissions globally as well as over the Indian subcontinent.

\section{Results}

Here we evaluate four model simulations each from HTAPII and CCMI, with a set of ground-based, satellite and airborne observations of $\mathrm{O}_{3}$; ground-based and airborne observations of $\mathrm{CO}$; and ground-based observations of $\mathrm{NO}_{x}$.

\subsection{Annual mean model-simulated surface ozone}

Figure 3 shows the spatial patterns of annual mean surface ozone mixing ratios from the model simulations described in Table 2 and the multi-model mean (MMM), shown in the lower right-hand panel. Ozone mixing ratios from the lowest model level are considered as surface ozone in this study. There is general agreement in the spatial characteristic of annual mean surface ozone across the models, except for HTAPII-HDGM (it shows different maxima and minima as compared to the other models). The range in area-weighted surface annual mean ozone is $22.9-35.3 \mathrm{ppb}$, with HTAPII- 

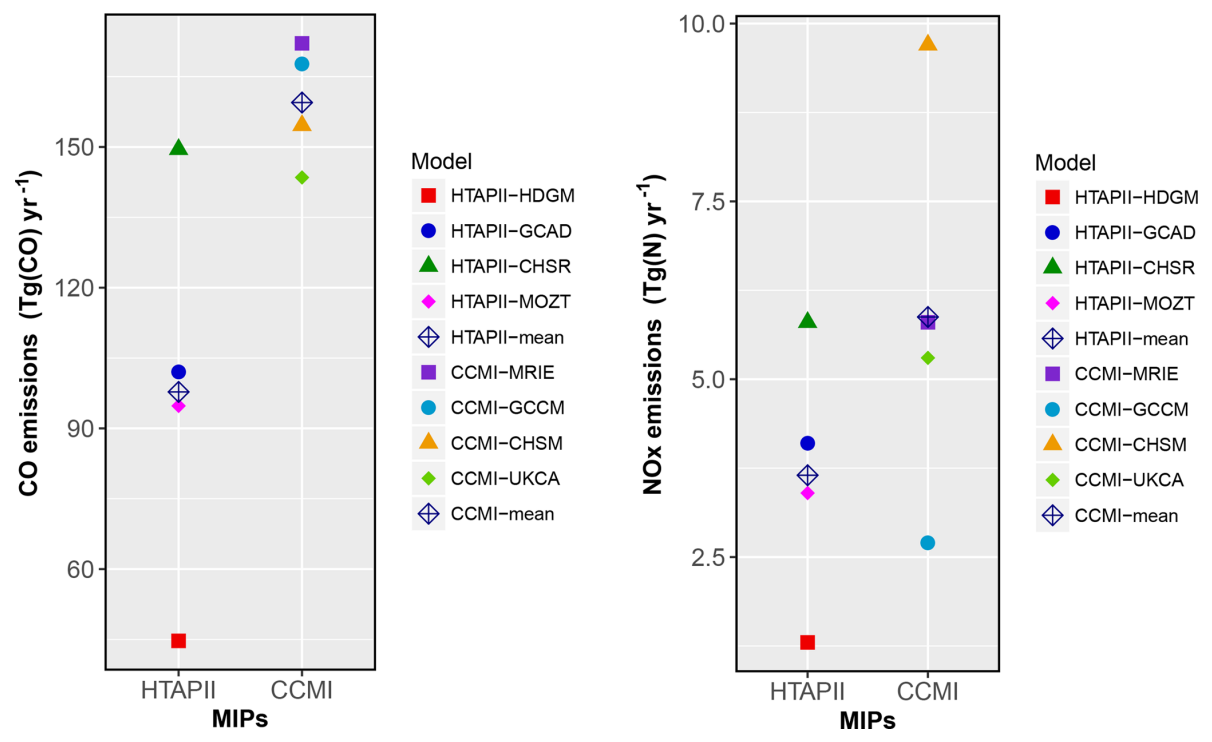

Figure 1. Shows the high variability in $\mathrm{NO}_{x}$ and $\mathrm{CO}$ emissions (anthropogenic + natural) between the two MIPs over the domain considered in this study. CCMI models show larger variability for $\mathrm{NO}_{x}$ emissions and HTAPII models shows larger variability for CO emissions.

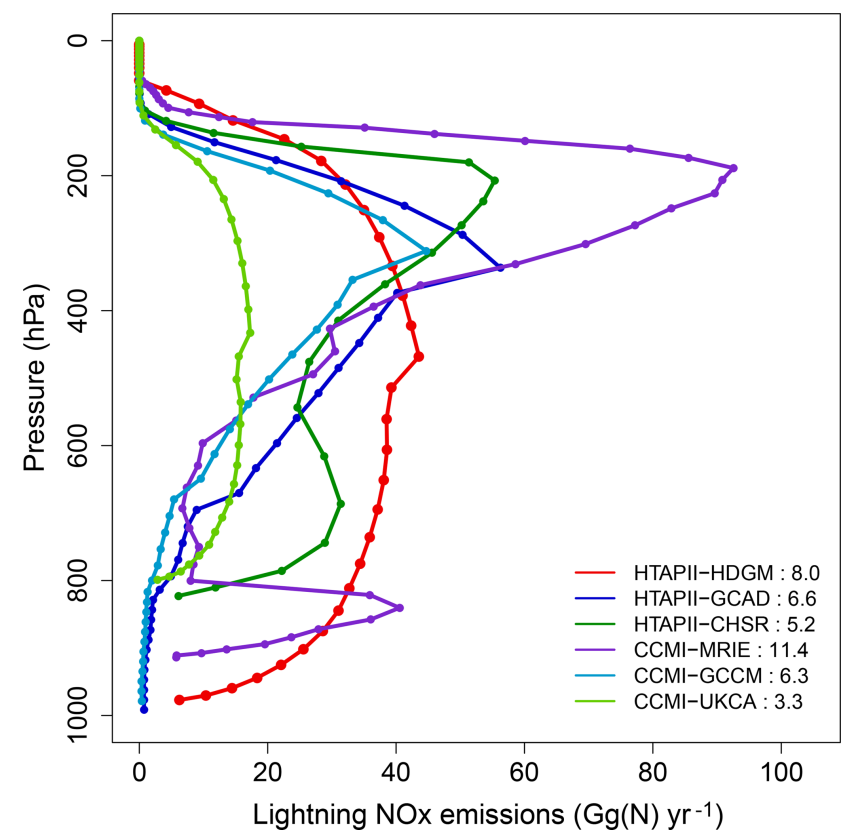

Figure 2. Annual vertical profiles of lightning $\mathrm{NO}_{x}$ emissions over the domain considered in this study (inset: global emissions of lightning $\mathrm{NO}_{x}$ in $\mathrm{Tg}(\mathrm{N})$ year $^{-1}$ as simulated by each model).

CHSR at the lower and HTAPII-MOZT at the upper end of the range, and the MMM value is $29.3 \mathrm{ppb}$. We also investigated the population-weighted surface annual average statistics using population data from NCAR climate and global dynamics (Gao, 2017; Jones and O'Neill, 2016). These data have a range of $28.5-38.85 \mathrm{ppb}$, with HTAPII-CHSR at the lower end and CCMI-UKCA at the upper end and a MMM of $33.0 \mathrm{ppb}$.

The MMM shows that the highest values of surface ozone are over the Tibetan plateau and northern part of India and the lowest values over the southern peninsula. However, whilst the models broadly agree on the regions of higher and lower ozone, there is significant intermodal variability in the magnitude of ozone concentration. Variations in models can be attributed to the different chemical schemes, physical parameterisations, grid resolution and non-anthropogenic emissions used in the models. CCMI-UKCA shows the highest values of surface mean annual average ozone compared to the other models. This may be attributed to the fact that CCMI-UKCA was designed for stratospheric chemistry and hence contains only a limited set of tropospheric chemistry reactions and no isoprene chemistry (more details in Sect. 2.2).

The standard deviation of the multi-model ensemble is shown in Fig. 4. The standard deviation of the multi-model mean can be used as an indicator of the level of agreement between the models. Here we show that there is a reasonably low level of agreement between the models, with an average of $23 \%$ standard deviation in the mean. This is slightly worse than the level of agreement between the ACCMIP models over the same region shown in Young et al. (2013) $(<20 \%$ standard deviation in the mean) and could reflect the fact that here we compare simulations from two different MIPs which make use of different emissions. However, we find the difference between the emissions within models of a particular MIP is as large as those between MIPs (Figs. 1, S2 and S3). Figure 4 highlights that models differ most in the northern and eastern part of India and standard deviation is the least in the central part of India. For the more well studied re- 

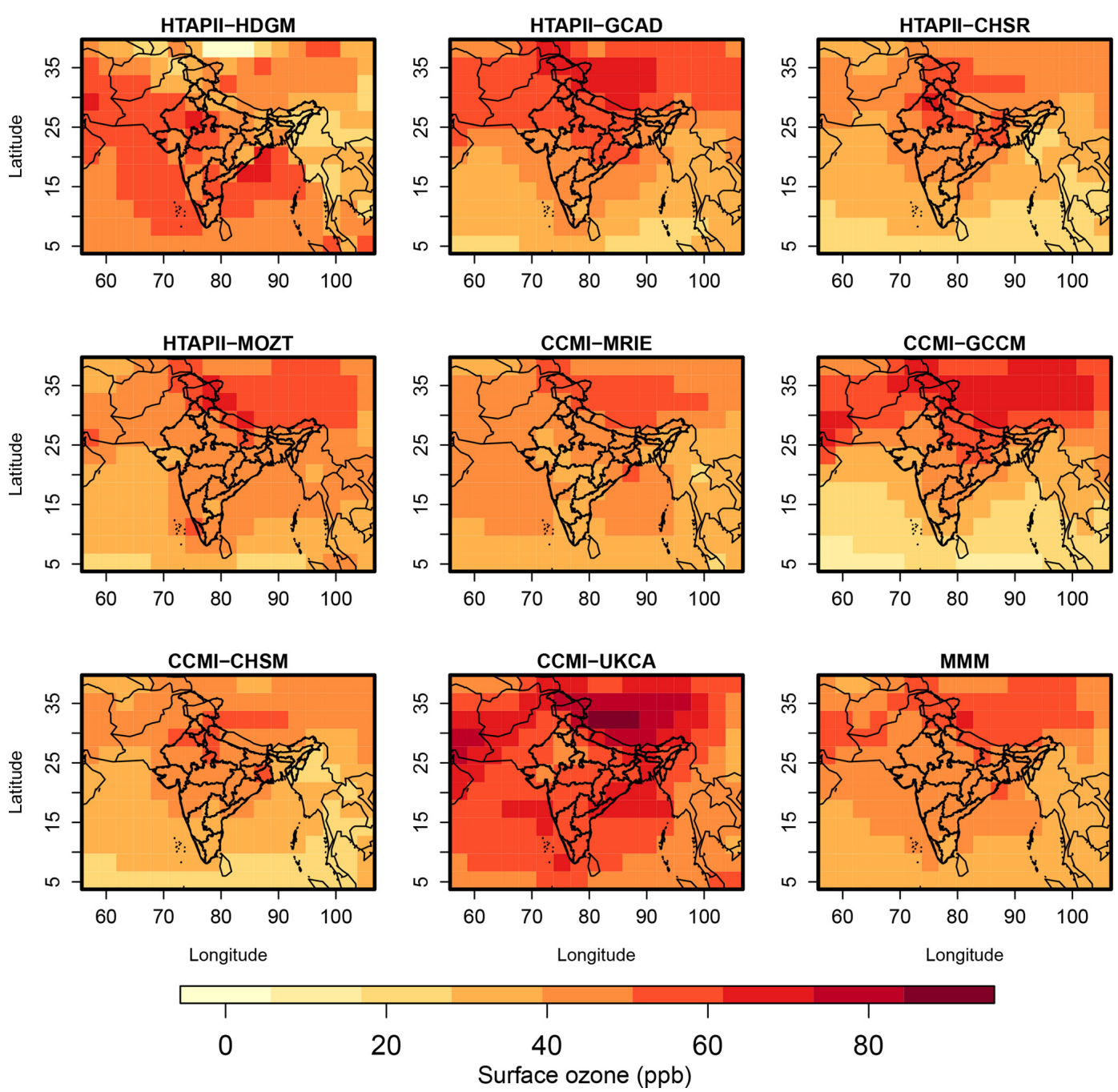

Figure 3. The spatial patterns of annual mean surface ozone (ppb) as simulated by the lowest level in each model, highlighting the regions where the models show maxima and minima over the Indian subcontinent.

gions such as North America and Europe, Young et al. (2013) show that global model multi-model analyses have similar if not slightly larger variability than over the Indian subcontinent. Young et al. (2013) show that the variability in the south-eastern USA is very high, $>30 \%$, across the ACCMIP models, which is likely linked to the impacts of different biogenic emissions (not specified in MIP protocols) and chemistry over this isoprene-rich area.

\subsection{Comparison between models and ground-based surface observations}

\subsubsection{Ozone}

Comparison of model-simulated monthly mean surface ozone with the monthly mean of hourly observations from the eight ground-based monitoring stations listed in Table 2 is shown in Fig. 5. In contrast to locations in Europe and
North America, but in agreement with previous observational analysis of surface ozone over India (Beig et al., 2007; Jain et al., 2005; Lal et al., 2012), our observational data highlight a double peak structure in the seasonal cycle of surface ozone. Cloudiness and wet scavenging of ozone precursors during the monsoon period (June-September) limit the photochemical production of ozone, resulting in lower values of ozone during these months. Due to favourable meteorological conditions during pre- (April-May) and post- (OctoberNovember) monsoon seasons, such as strong solar radiation, high temperature and low humidity, photochemical production of ozone is enhanced during these months. Emissions from biomass burning also contribute to ozone production during the post-monsoon season at sites such as Delhi and Patiala. The seasonal variability in the models is captured fairly well at all stations, except at Chennai. Figure 5 includes the MMM and standard deviation (dark dashed blue and light blue envelope), which can be compared with the 


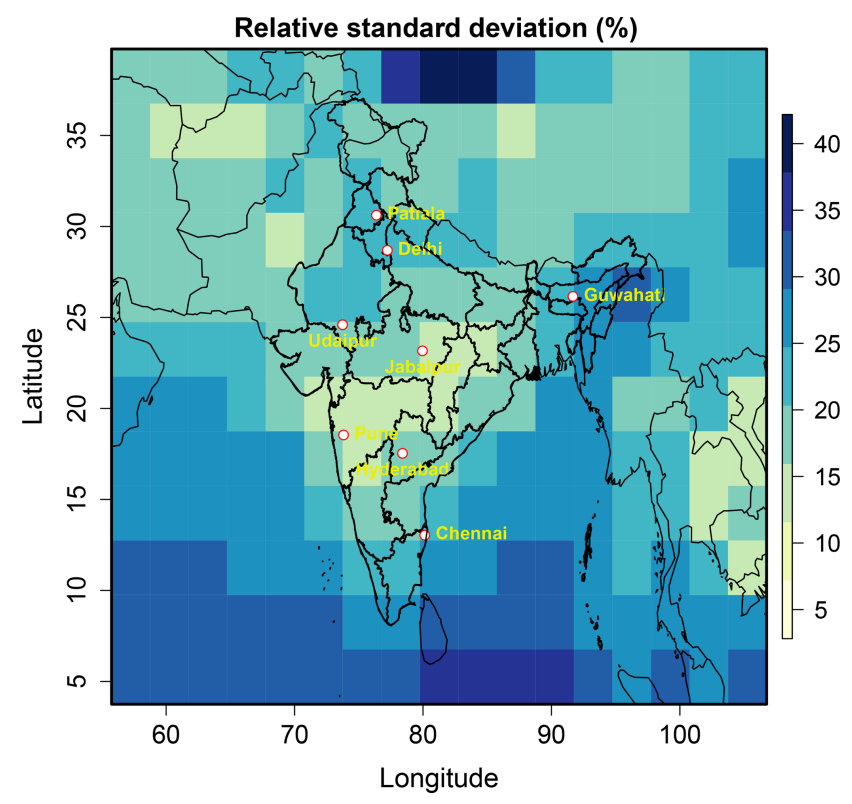

Figure 4. Relative standard deviation of surface ozone from the eight models. The plot also shows the location of ground-based observational MAPAN stations considered in this study.

mean and standard deviation of the observations (solid black line and grey envelope). In seven out of eight cases, the ozone mixing ratio is higher in the MMM than in the observations (except at Jabalpur, where MMM is within $1 \sigma$ deviation). The overestimation by the models is due to the overestimation in production and/or the underestimation of loss of ozone. This could be attributed to a combination of factors. The principal factor is most likely a mismatch in the representativeness of the observational sites for comparison with the coarse-resolution models. At coarse resolution, the models cannot capture fine-scale processes, such as the impact of nearby sources of pollution (e.g. $\mathrm{NO}_{x}$ emissions) on the observations of ozone. Ozone production is highly non-linear in terms of the precursor emissions VOCs and $\mathrm{NO}_{x}$ (Monks et al., 2015). Figure 5 also highlights differences between the models. There is considerable inter-model variation in simulating the seasonal variation in surface ozone, as we discuss in more detail below.

To evaluate the performance of models at each station we compare the normalised mean biases (NMBs) and Pearson correlation coefficient $(R)$. These were calculated using the following equations:

$\mathrm{NMB}=\frac{\Sigma \text { Model }-\Sigma \text { Obs }}{\Sigma \text { Obs }}$,

$R=\frac{\overline{(\text { Model }[\mathrm{i}]-\overline{\mathrm{Model}}) \times(\mathrm{Obs}[i] \overline{\mathrm{Obs}})}}{\sigma(\text { Model }) \times \sigma(\mathrm{Obs})}$,

where $\sigma$ is the standard deviation.
Figure 6 shows the relationship between $R$ and NMB for each of the models we have studied, as well as the multimodel mean, at each of the surface site locations. As is evident from Fig. 5, all models show a positive NMB at all stations. All models have low biases and high $R$ values (except for CCMI-UKCA) at Jabalpur and Pune. Models show high biases at Guwahati and Chennai, and low $R$ values at Chennai and Udaipur. Observations at Chennai peak in April and October, i.e. during pre- and post-summer monsoon seasons. Models show poor correlation with the seasonal cycle of ozone at Chennai. To some extent this might be affected by the model's ability to simulate summer monsoons (from the south-west) and winter monsoons (from the north-east) that affect Chennai. It would be worth comparing model simulations with ozone observational data at Mumbai on the west coast of India, which receives rainfall only during the summer, to understand the role of the monsoon near these coastal sites, and we suggest further analysis assessing the performance of the models at the coastal impacted locations specifically. Overall, the performance of the models across all the sites is inconsistent. There is no one model that performs systematically well at all stations. Conversely, the models perform differently at each station in terms of their $R$ value and NMB. Unlike in previous studies (e.g. Young et al., 2013) the MMM also does not outperform the individual models in Fig. 5. CCMI-UKCA acts as an outlier at five out of eight sites. The impact of the underlying emission biases can be seen by comparing the results between HTAPII-CHSR and CCMI-CHSM in this study. These are in effect the same model (see Sect. 2.2) but include different emissions data as part of the different MIP protocols. Figure 6 shows that these two simulations result in large differences at only one of the eight sites investigated (Chennai), whereas the difference between different models in the same MIP is typically much larger. This implies that the differences between the simulations are more down to the differences in model set-up, representation of chemical and physical processes, and nonanthropogenic emission sources in the models than the differences in anthropogenic emissions between the two MIPs.

In order to better understand the causes of biases between the model and observations shown in Figs. 5 and 6, $24 \mathrm{~h}$ average model and observation data have been analysed to determine probability density functions (PDFs) as shown in Fig. 7 for a subset of the sites considered (Delhi, Pune, Guwahati and Chennai). The PDFs for the observations show a multimodal distribution (with 2-3 modes most common) with the highest peak at lower ozone values. This pattern is typical of situations in which nearby sources of $\mathrm{NO}_{x}$ titrate ozone, through the following reaction:

$\mathrm{O}_{3}+\mathrm{NO} \rightarrow \mathrm{NO}_{2}+\mathrm{O}_{2}$.

The observed PDFs are typically low in Guwahati and Chennai, whereas Delhi and Pune show several days where high levels of ozone are seen, especially in Pune where daily average ozone can be as high as $97 \mathrm{ppb}$. 

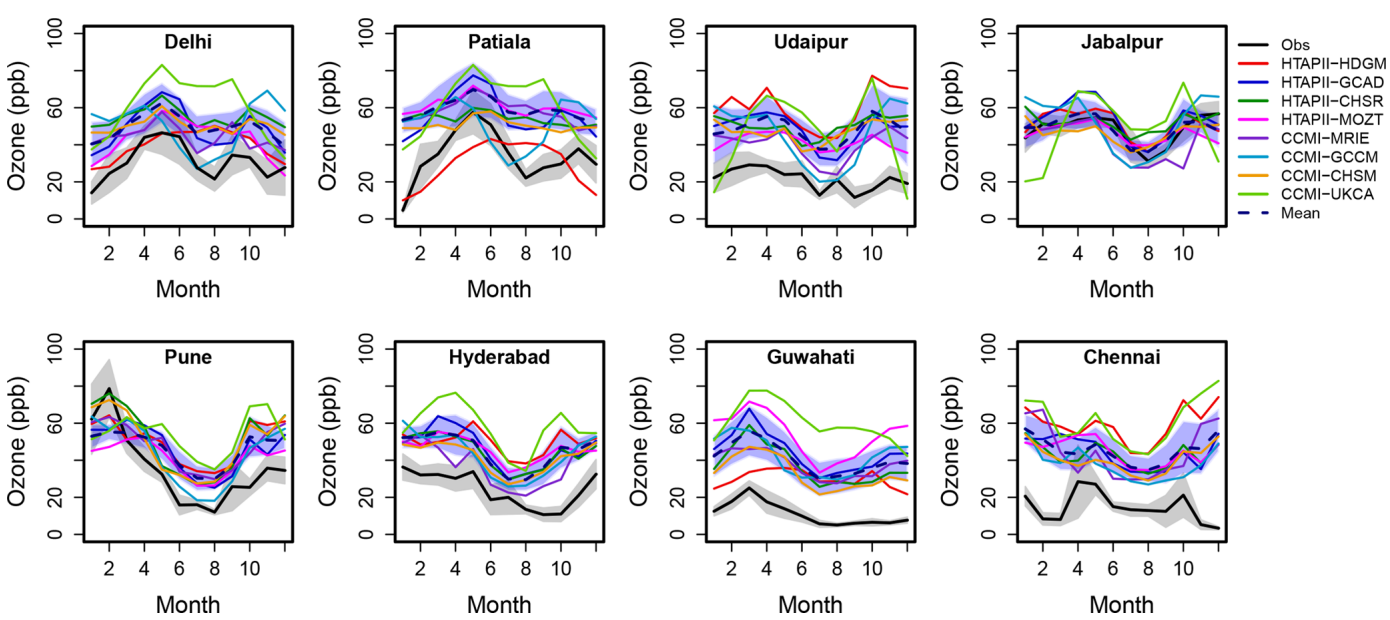

Figure 5. Comparison between ground-based observations, model-simulated data and the ensemble mean of monthly mean surface ozone over the eight MAPAN stations.

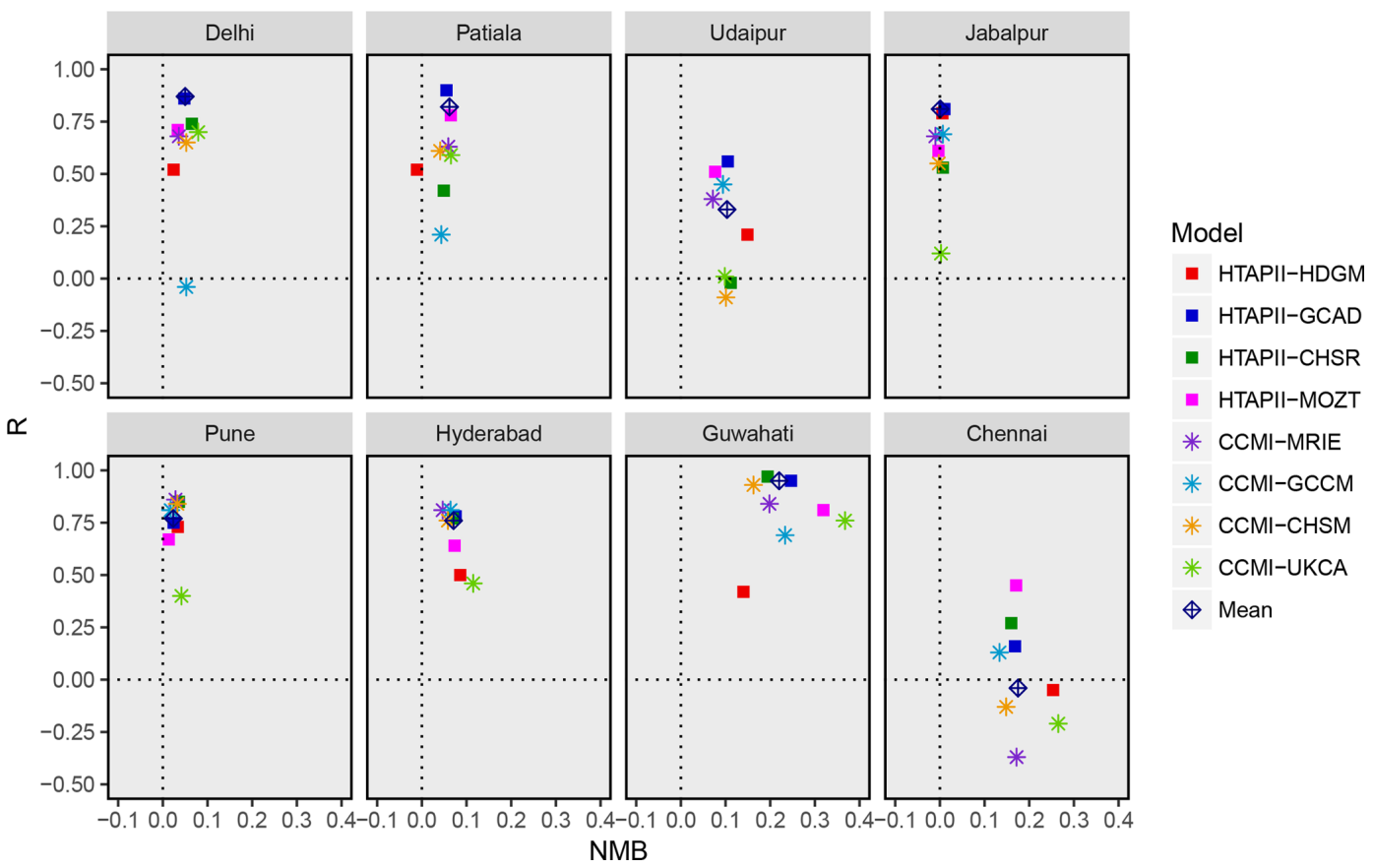

Figure 6. Scatter plot of Pearson correlation coefficient $(R)$ values against normalised mean bias (NMB), highlighting the models performance in surface ozone at each station.

The PDFs for the model simulations also show a multimodal distribution but the nature of their distributions is very different from the observed distribution. Moreover, the differences between the simulation PDFs is larger than the differences between the multi-model mean and the observations. Again, this highlights the large variability among models in their simulation of ozone in these regions. The most obvious feature from Fig. 7 is that the models overestimate the PDFs at the four sites and significantly overestimate the tails of the ozone distributions. As well as overestimating the ozone concentration at the modes, in most models the high- est peak is at the second mode with higher ozone values, in contrast to the observations where the highest peak is usually at lower ozone concentrations. The amplitude and shift in the PDF peaks compared to observations is greatest at Guwahati and Chennai. This may be due to the inability of the models to adequately simulate $\mathrm{NO}_{x}$ titration at these sites, which occurs at a finer scale than can be resolved by the coarse model grids. Studies have shown that the model's ability to simulate surface ozone is very sensitive to horizontal resolution and high-resolution models generally perform better when compared to observations (Stock et al., 2014). 

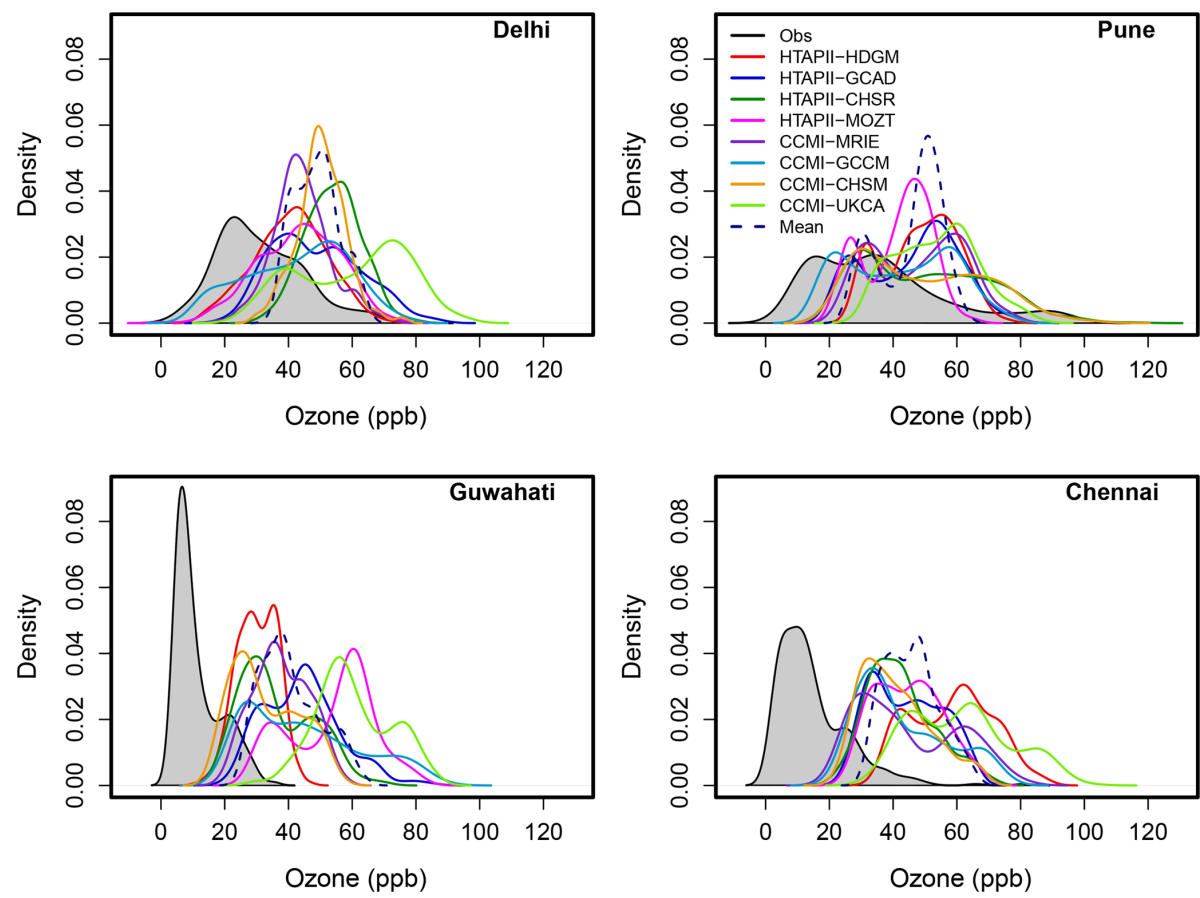

Figure 7. Probability density functions (PDFs) for in situ observations and model-simulated 24 h average surface ozone at Delhi, Pune, Guwahati and Chennai.

\subsubsection{Ozone precursors}

When compared with the set of available surface ozone observations we have used, the current state-of-the-art global chemistry models overestimate surface ozone in India. There is a large amount of variability among the models, much larger over India than in previous model inter-comparisons over the northern and southern hemispheres (Young et al., 2013). In order to better understand the variation in ozone, we have also compared the model simulations of $\mathrm{NO}_{x}$ and carbon monoxide at the eight sites that form part of the MAPAN network. Similar to Fig. 5, Fig. 8 shows the seasonal variation in surface $\mathrm{NO}_{x}$ in the models and observations. The observations of $\mathrm{NO}_{x}$ (black line with grey envelope) vary from location to location. High values are observed during autumn-winter due to the transport of pollutants from polluted regions, such as the IGP region, through north-easterly winds. During the winter months $\mathrm{NO}_{x}$ emissions are trapped closer to the surface due to low boundary layer heights, caused by frequent temperature inversions, while in summer months south-westerly winds bring in clean marine air to almost the entire Indian region and there is greater mixing with free tropospheric air, causing dilution of pollutants in general (Beig et al., 2007; Jain et al., 2005; Lal et al., 2012). Figure 8 shows that in Pune, Guwahati and Jabalpur, the highest observed monthly average $\mathrm{NO}_{x}$ is seen in the winter months. In Delhi and Patiala, the pre- and post-monsoon season (when biomass burning is high) are when $\mathrm{NO}_{x}$ levels are at their highest levels, with lower levels of $\mathrm{NO}_{x}$ in the monsoon months. Figure 8 highlights that there is a large range of $\mathrm{NO}_{x}$ values in the observations, with Delhi having the largest monthly average levels of $\mathrm{NO}_{x}$ of up to $180 \mathrm{ppb}$ (November) and Chennai having the lowest levels of $\mathrm{NO}_{x}$ (8 ppb, November).

Comparing the observations and the MMM highlights that on average the simulations underestimate levels of $\mathrm{NO}_{x}$ at these eight locations across India. An exception is for HTAPII-HDGM at Patiala, where the model simulation overestimates the levels of $\mathrm{NO}_{x}$ present. The monthly average $\mathrm{NO}_{x}$ in the model simulations at all sites is dominated by $\mathrm{NO}_{2}$ whereas in observations at Delhi (the only site for which separate measurements of $\mathrm{NO}$ and $\mathrm{NO}_{2}$ are available), $\mathrm{NO}$ dominates monthly average $\mathrm{NO}_{x}$ (see Sect. S4 in the Supplement). This discrepancy could be attributed to the coarse resolution of the models, meaning high $\mathrm{NO}_{x}$ emissions are diluted over a larger volume of air. Hence, models underestimate ozone titration due to high levels of NO near emission sources, which results in the overestimation of surface ozone and a photo-stationary state with greater proportion of $\mathrm{NO}_{x}$ as $\mathrm{NO}_{2}$.

Figure 9 shows a comparison of the observed and modelsimulated $\mathrm{CO}$ at the different sites across India we focus on here. At the majority of the other sites considered, there is a clear seasonal cycle in $\mathrm{CO}$, with peaks in the winter months and minimum values during the summer and monsoon period. As with $\mathrm{NO}_{x}$ (Fig. 8), Delhi is the region with the highest observed values of carbon monoxide, and the highest levels of $\mathrm{CO}$ occur in the pre- and post-monsoon period (con- 

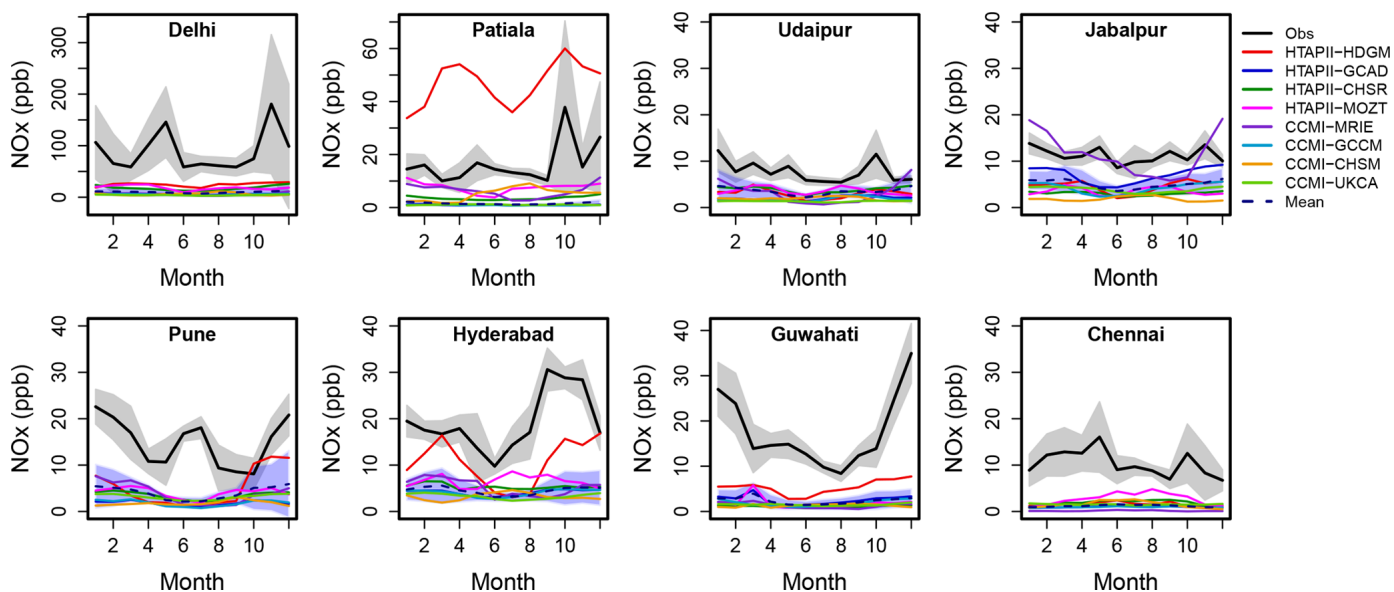

Figure 8. Comparison between ground-based observations and model simulations of monthly mean surface $\mathrm{NO}_{x}$ over the eight MAPAN stations. A different scale has been used for Delhi and Patiala.
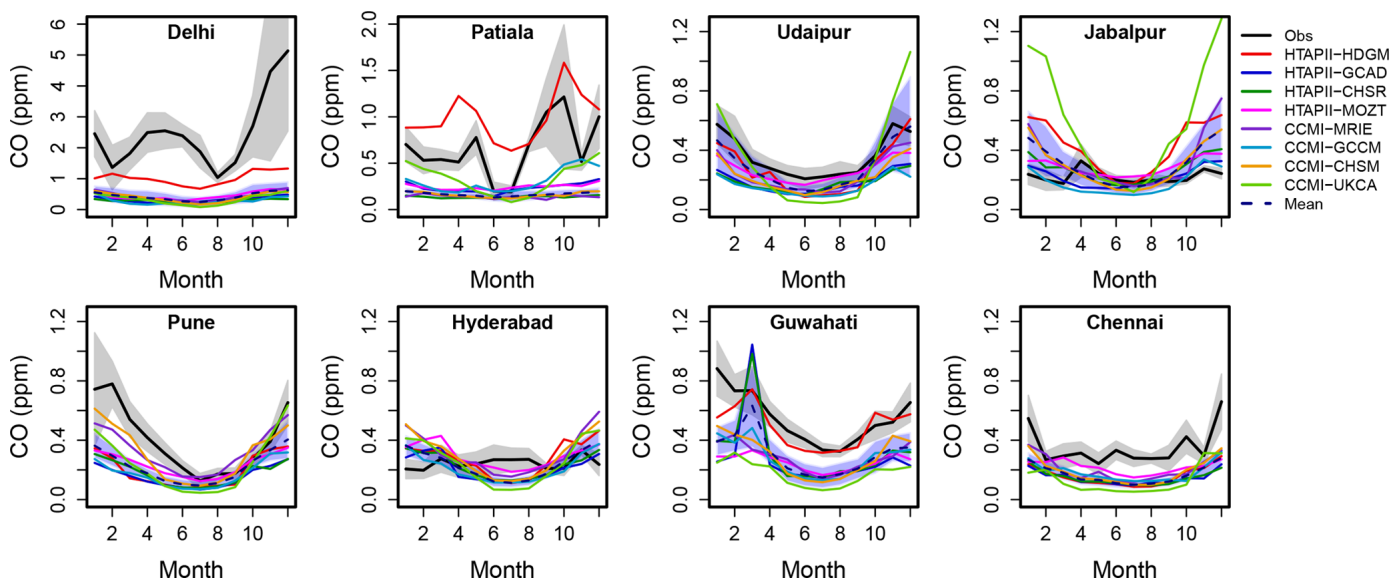

Figure 9. Comparison between ground-based observations and model simulations of monthly mean surface CO over the eight MAPAN stations. A different scale has been used for Delhi.

sistent with the periods of highest agricultural burning). The variations in observed carbon monoxide are caused by a combination of factors, including changes in the strength of direct emissions of CO (Fig. S5) as well as the contribution of secondary sources such as the oxidation of VOCs (Grant et al., 2010), variations in the boundary layer height and changes in local wind patterns (Ahammed et al., 2006).

The model simulations capture the seasonal variability in monthly mean $\mathrm{CO}$ well ( $R$ values $>0.4$ for all models) at most locations; the exception is in Hyderabad, where all models generally show a negative correlation with the observations, and at Jabalpur, where correlation is poor (see Sect. S5). Interestingly, the model simulations at Jabalpur and Hyderabad show the lowest correlations with the observations in spite of having the lowest biases. This could point towards some important processes which the models are struggling to simulate, but further work would be needed to clarify this. The site with the best correlation is Udaipur, where the MMM correlation coefficient is 0.96 . Models are in agreement with the observed $\mathrm{CO}$ at all sites but highly underestimate the observed values at Delhi and Patiala. As with $\mathrm{NO}_{x}$, an exception is HTAPII-HDGM, which tends to overestimate $\mathrm{CO}$ at Patiala, but with good correlation ( $R$ value of 0.63 ), picking up the peaks in pre- and post-monsoon $\mathrm{CO}$ associated with burning.

\subsection{Comparison between models and satellite data}

\subsubsection{Annual average tropospheric ozone column (AATOC)}

Figure 10 shows the annual average tropospheric ozone column (AATOC) retrieved by the OMI/MLS for the year 2010 on board the AURA satellite and the model simulations. The OMI/MLS AATOC shows the highest values (45-60 Dobson units) over the IGP and the central and north-western regions of India. These high values are not uncommon globally (Gaudel et al., 2018). High levels of AATOC are associated 

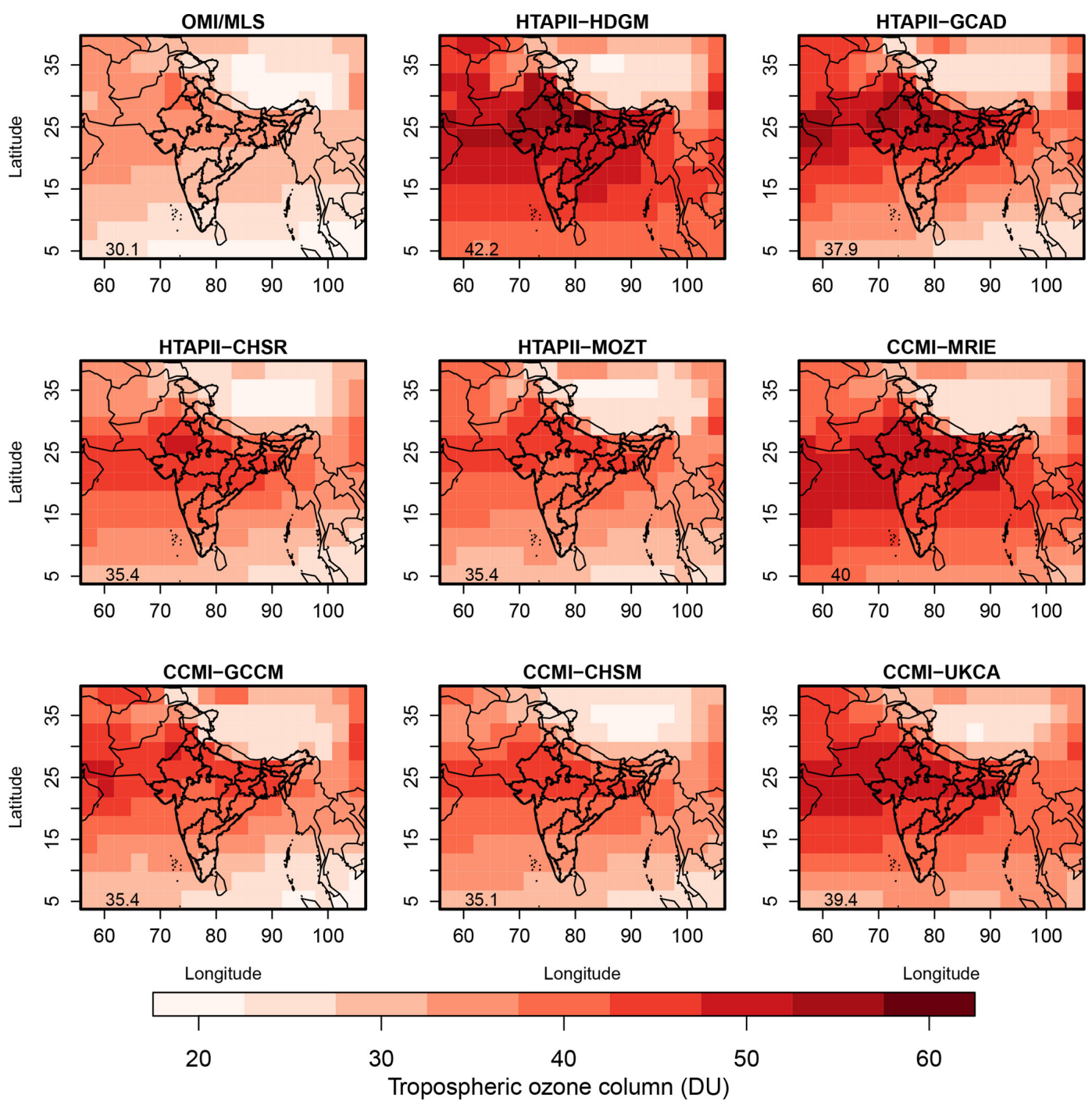

Figure 10. OMI/MLS-determined and model-simulated annual average tropospheric ozone column (AATOC) in Dobson units (DU) over the Indian subcontinent. Values in the bottom left corner indicate the mean AATOC in the domain.

with high anthropogenic activities and large-scale biomass burning. The IGP and the regions of India mentioned above are examples of regions affected by these sources. Lower values of AATOC are observed over the maritime regions and a minimum is observed over the Tibetan plateau. The seasonal cycle of tropospheric ozone column (TOC) peaks in MayJune and is fairly widespread over India. The onset of the monsoon leads to lower levels of TOC across the region on the whole. Hence, differences in emissions are not the only factor that leads to differences in the observed AATOC values; regional variations in meteorological conditions are also an important factor that controls AATOC (David and Nair, 2013).

In order to evaluate the model simulations and observations we first compare the mean total ozone column (MTOC), defined as the spatial mean of AATOC over the study do- main. Over the entire region we focus on $\left(56\right.$ to $105^{\circ}$ longitude and 5 to $38^{\circ}$ latitude), the MTOC from OMI/MLS is 30.1 DU. Models overestimate the MTOC over this region (see Fig. 10), with MTOC values for models ranging from 35 to 42 DU. HTAPII-HDGM shows the highest bias $(\sim 40 \%)$ and HTAPII-CHSR, HTAPII-MOZT and CCMIGCCM show the lowest bias $(\sim 16 \%)$. It is worth noting that the AATOC values are not the highest for CCMI-UKCA, even though the annual average surface ozone values are the highest for CCMI-UKCA as compared to the other models.

The differences between the OMI/MLS observations and the model simulations are further highlighted in Fig. 11, where the percentage biases in AATOC are shown. The model simulations, in general, show similar spatial patterns in AATOC to OMI/MLS, but all models overestimate the total TOC values over the domain. The total TOC values 

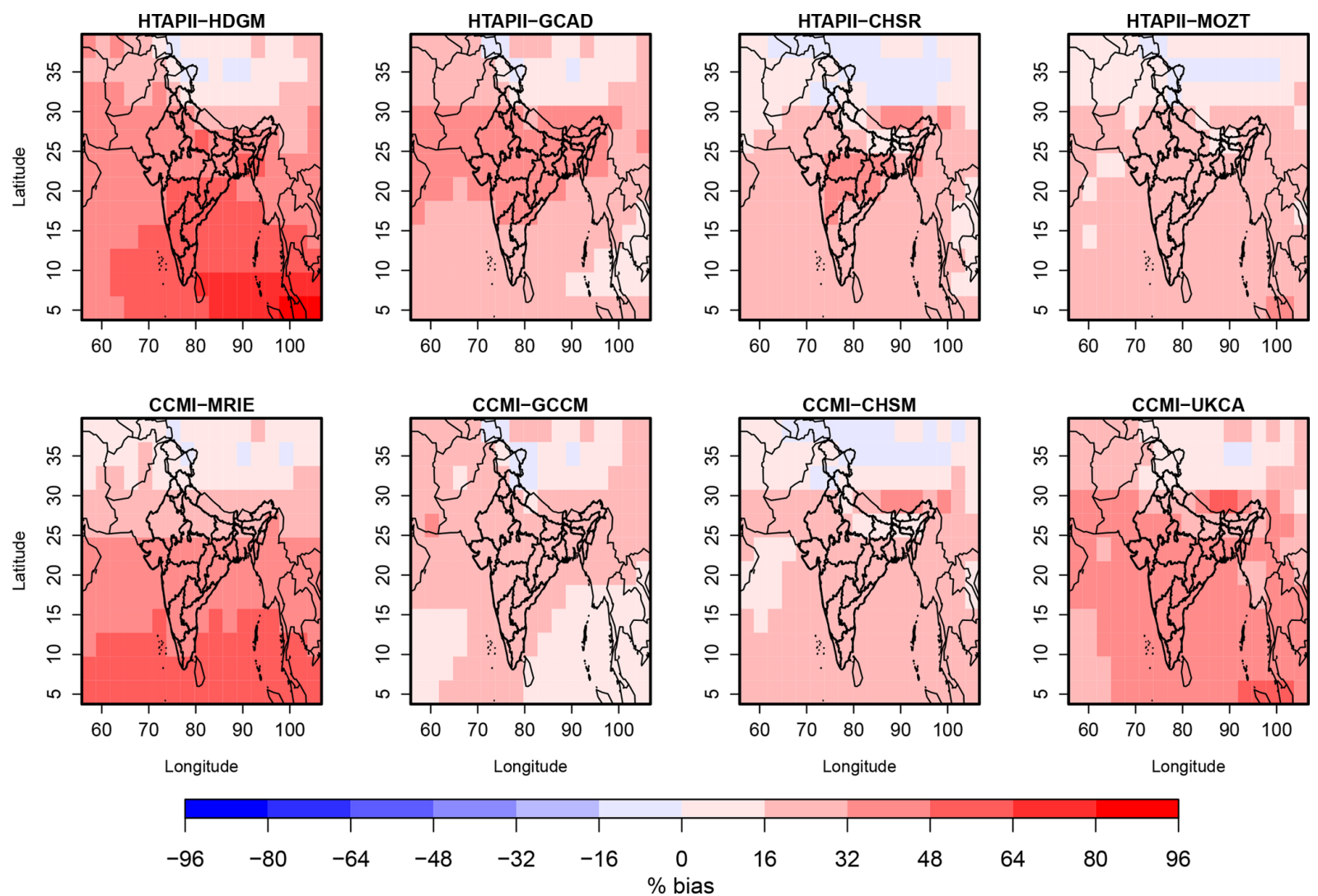

Figure 11. Percentage biases in model-simulated AATOC with respect to the OMI-determined AATOC.

for HTAPII-CHSR and CCMI-CHSM are somewhat different and show different bias patterns in spite of having same chemistry schemes and being based on the same model. However, the differences between different models in the same MIP (i.e. between HTAPII-CHSR and the other HTAPII models, or between CCMI-CHSM and the other CCMI models) are typically larger, both in terms of the average total TOC over the domain and the spatial distribution. Thus, there is greater inter-model variation due to model setup (either differences in model chemistry schemes, dynamics or non-anthropogenic emission sources) than due to differences in anthropogenic emissions prescribed by the two MIPs.

\subsubsection{Empirical orthogonal function analysis}

Several previous studies have focused on harmonic or spectral analysis of time series of ozone in both observations and models (Bowdalo et al., 2016; Derwent et al., 2013; Parrish et al., 2014; Solazzo et al., 2017). A key goal of the studies and types of analysis above is to determine the causes of biases between models and observations to enable improvements in modelling of ozone. Typically spectral analysis allows the complex time series present in an ozone dataset to be decomposed into a set of spectral features. Studies have applied these methods to many parts of the world such as Europe, North America and Australia (e.g. Derwent et al., 2013; Young et al., 2013; Bowdalo et al., 2016), but to date no study has applied spectral analysis on global model and observed ozone across India.

In this study, we have used EOF analysis on the OMI/MLS-observed and the model-simulated TOC from HTAPII and CCMI. EOF analysis reduces the dimensionality of the input spatial variables (i.e. ozone column, which is $f$ (lat, long, time)) to find new sets of variables that capture most of the observed variance from the original data through a linear combination of the original variables. Principle components (PCs) represent the sign and overall amplitude of the EOF as a function of time. EOF analysis is commonly used in the climate science community (Nair et al., 2014) but has been less widely used in the ozone modelling community. EOF analysis is analogous to Fourier transform (FT) analysis but performs better than FT when the signal differs from the pure sinusoidal waveform (Cepeda and Colome, 2014).

EOF analysis was applied to both the OMI/MLS and modelled TOC across a domain of 56 to $105^{\circ}$ longitude and 5 to $38^{\circ}$ latitude, which covers the entire Indian subcontinent. Figure 12a depicts the spatial patterns of EOF1, which explains the maximum variance in tropospheric ozone over the domain. EOF1 has a loading for each variable; in this case the 
variables are the grid points, they have correlation structures both in space and time. The amplitudes of the EOF1 spatial patterns have a time series as shown by PC1 in Fig. 12b.

The spatial patterns depicted by EOF1 (Fig. 12a) for models are similar to the spatial pattern for the OMI/MLS observations: they show higher values in the north-western part of domain and lower in the southern part and over the ocean. However, the magnitudes of the loading are different between each of the models and between the MMM and the observations.

The amplitude of EOF1 (Fig. 12b) has negative values in winter and positive values during the summer monsoon seasons. There is a discernible difference in the phase of PC1, with most of the models peaking in July-August, but the observations peaking in June. The annual-cycle-like structure of PC1 shows a strong correlation with the movement of the intertropical convergence zone (ITCZ) over India, which heads southward during winter and northward during summer. Physically these spatial patterns thus represent surface pressure changing with the movement of ITCZ. Precipitation also migrates with ITCZ over India. Hence maximum variance in tropospheric ozone is explained by the monsoon over South Asia (i.e. EOF1 reflects the monsoon). It is worth noting that the maximum variance in tropospheric ozone column explained by EOF1 in observations is $\sim 60 \%$ whereas in models it is greater than $70 \%$. The maximum variance in tropospheric ozone column explained by EOF1 in CCMIUKCA is $\sim 55 \%$, which is less than that of the observations. The differences in the EOF1 spatial pattern, the amplitudes of EOF1 (as given by the PC1) and the percentage of maximum variance explained indicate that each model is capturing monsoons differently both in space and in time.

In spite of reasonable agreement between the models and observations for EOF1 and PC1, the comparison for EOF2 and $\mathrm{PC} 2$ is poor (Fig. S2a and b). There is no agreement between the spatial pattern of EOF2 and the amplitude of EOF2 (PC2) among the models and OMI-MLS. Whilst this EOF analysis has provided a novel approach to comparing and contrasting the modelled and observed tropospheric ozone column distributions, it does not give a clear understanding about the underlying reasons for the discrepancies in the models, as with many of the previous studies (Bowdalo et al., 2016; Derwent et al., 2013; Parrish et al., 2014; Solazzo et al., 2017).

\subsection{Comparison with the IAGOS-CARIBIC observations}

We now focus on the comparison of the model data to vertical profiles of carbon monoxide and ozone measured on board a commercial airliner as part of the IAGOS-CARIBIC programme (Brenninkmeijer et al., 2007). The observations from IAGOS-CARIBIC are important as they provide a connection between the surface and satellite observations dis- cussed above, but they are statistically less powerful owing to small samples sizes.

Figure 13 shows the seasonal mean vertical profiles of ozone and carbon monoxide from the IAGOS-CARIBIC aircraft observations from Lufthansa flights LH758 and LH759, which connect between Frankfurt, Germany, and Chennai, India, compared with model output over Chennai. In total we have combined the results from over 16 flights during April to December 2008. We have converted the IAGOSCARIBIC data into pseudo-climatological data, by averaging over $25 \mathrm{hPa}$ vertical bins as explained in Sect. 2.1.2, to enable a comparison of the models pre-monsoon, post-monsoon and during the monsoon. The black lines in Fig. 13 denote the average observed vertical profile, with the grey envelope reflecting the standard deviation in these average observations. Model data refer to the average monthly mean model profiles over Chennai airport that coincide with aircraft and are also interpolated to $25 \mathrm{hPa}$ vertical pressure bins.

During the pre-monsoon season (April-May), high values of ozone and $\mathrm{CO}$ are observed in the lower troposphere (LT) $(p>500 \mathrm{hPa})$ as compared to the upper troposphere (UT) $(p<500 \mathrm{hPa})$. Generally speaking, models underestimate the ozone and $\mathrm{CO}$ values in the LT and perform fairly well in the UT. Given the fact that these are very limited observational data, any specific emission events (for example wild fires) that occurred during the observing period are unlikely to be reproduced by the models (Ojha et al., 2016). The levels of model-simulated CO in the pre-monsoon LT generally show higher biases as compared to the ozone levels. HTAPII-MOZT simulates the pre-monsoon LT carbon monoxide levels in good agreement with the observations but highly overestimates the UT values and generally overestimates the $\mathrm{CO}$ mixing ratios in the post- and monsoon periods. CCMI-UKCA highly underestimates the $\mathrm{CO}$ profiles, especially in the UT. HTAPII-HDGM performs well in the LT for ozone profiles during the pre-monsoon season.

Chennai experienced a strong pollution event on 15 July 2008 (Ojha et al., 2016), hence high values of ozone are observed between 900 and $850 \mathrm{hPa}$ during the monsoon season (June-September). Since the model ozone values are monthly mean values, models do not capture this strong pollution event. Aside from this event, models capture the ozone and $\mathrm{CO}$ profiles well during the monsoon season; the MMM bias is $\sim 11 \%$ for ozone and $\sim-5 \%$ for $\mathrm{CO}$ and the correlation coefficient is $\sim 0.29$ for ozone and $\sim 0.7$ for CO. HTAPII-HDGM and CCMI-UKCA tend to overestimate the ozone profile in the UT whilst HTAPII-MOZT overestimates and CCMI-UKCA underestimates the $\mathrm{CO}$ profiles in the monsoon season.

There are large discrepancies between the models and IAGOS-CARIBIC observations in the LT during the postmonsoon season. Models overestimate the ozone and carbon monoxide profiles by a factor of 1.5 and 1.7 , respectively, in the LT during the post-monsoon season (OctoberDecember). However, the models agree much better with 

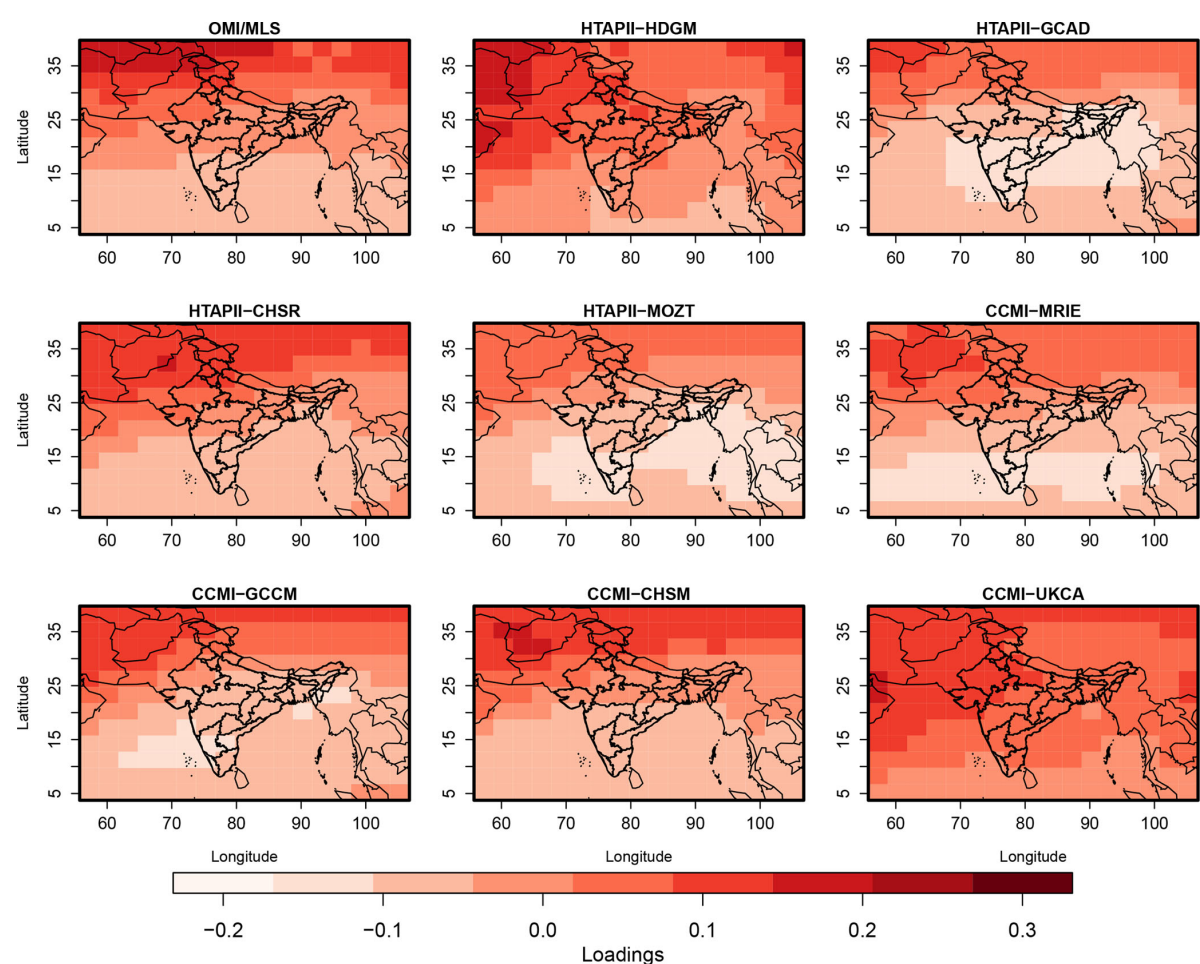

Principle component 1

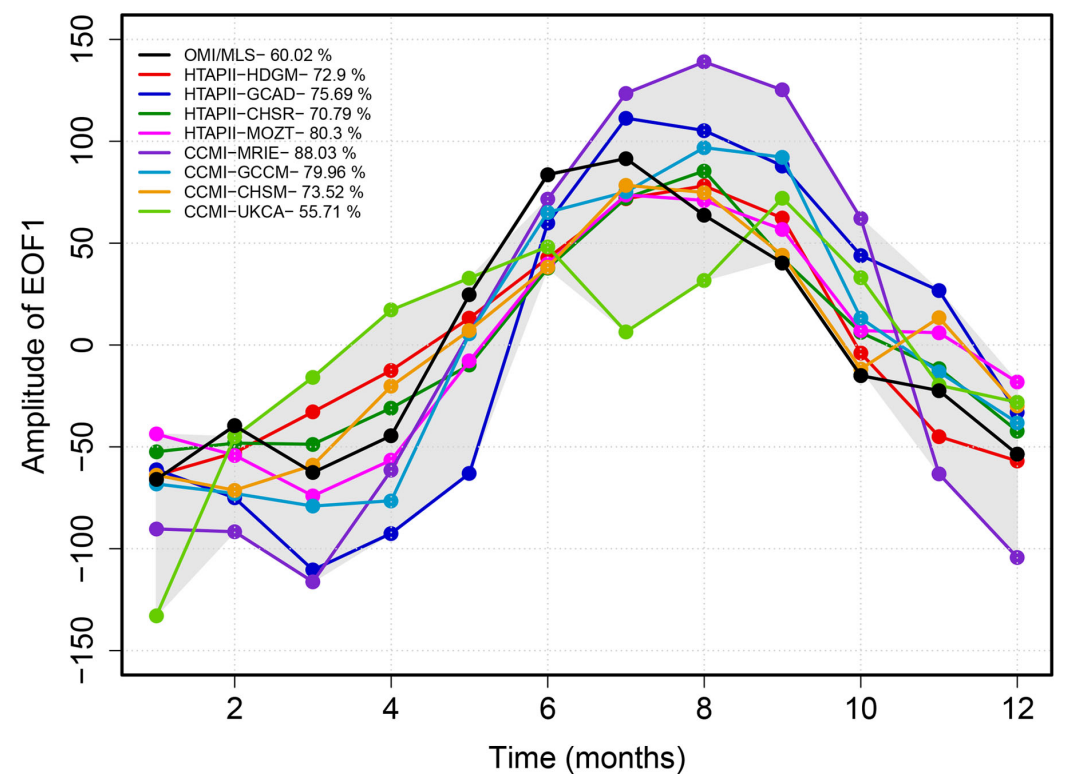

Figure 12. (a) Dominant spatial pattern (i.e. EOF1), which explains the maximum variance in the tropospheric ozone column. (b) Time series of the amplitude of EOF1 (PC1) with the values of accounted variance by the EOF1 in the legend for each model.

the observed ozone and carbon monoxide profiles in the UT during this season. HTAPII-MOZT overestimates the carbon monoxide profile in the UT. The majority of the other models tend to have fairly high levels of carbon monoxide "trapped" within the boundary layer during the postmonsoon period. There is little evidence for this trapping in the IAGOS-CARIBIC observations, but more evidence for pollutant $(\mathrm{CO})$ build-up in this season can be seen in the surface data analysed in Sect. 3.2.2.

The comparison of the HTAPII and CCMI models to these aircraft data has been useful in basic evaluation of the vertical profiles of these key pollutants. However, the limited number of observed vertical profiles of these pollutants restrict detailed evaluation of models over this region. Moreover, tar- 

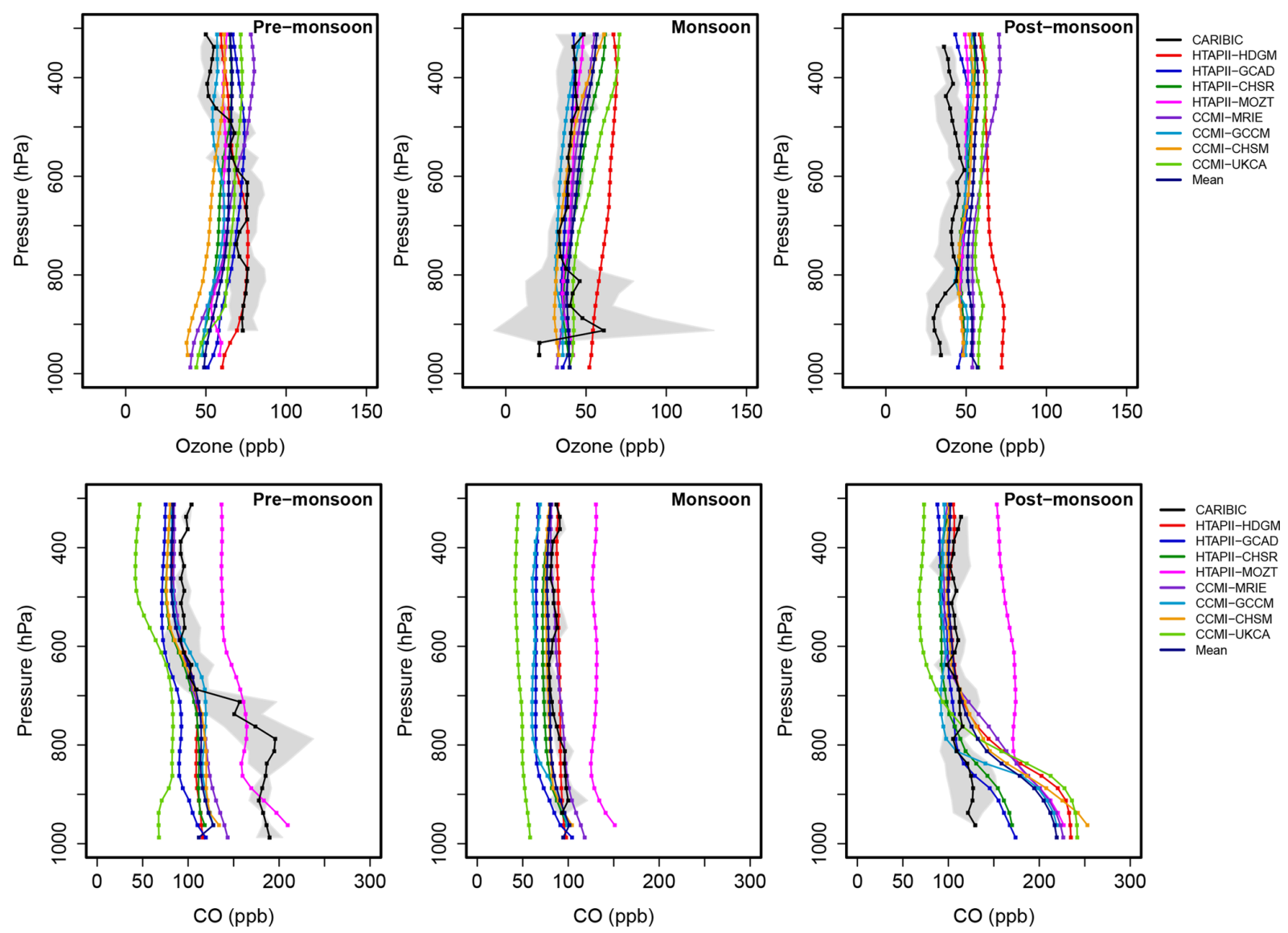

Figure 13. Comparison of ozone and carbon monoxide profiles from model simulations, 2009-2010, with the CARIBIC observations in Chennai for pre-monsoon (April-May), monsoon (June-September) and post-monsoon (October-December) seasons, 2008. Model simulations have been vertically interpolated along the CARIBIC flight pressure levels. The mean of the data collected during the aircraft descent and ascent is shown here.

geted aircraft-based studies would be illuminating, especially with comprehensive chemical and aerosol measurements to enable improvements in modelling in this region.

\subsection{Ozone as a function of VOC and $\mathrm{NO}_{x}$ emissions}

Finally, in order to evaluate how the models are simulating ozone at the surface, we extend the analysis of surface ozone shown in Fig. 3 to contrast the model-simulated surface ozone against the model input VOC and $\mathrm{NO}_{x}$ emissions following Squire et al. (2015) by creating ozone isopleth plots. Figure 14 shows the isopleths of surface ozone concentrations as a function of $\mathrm{NO}_{x}$ and $\mathrm{VOC}$ emissions for a subset of models (HTAPII-GCAD, HTAPII-CHSR, CCMIGEOSCCM and CCMI-CHSM) over the entire domain of study. These models were chosen as they include (i) essentially the same model run for the two different MIPs (HTAPII-CHSR and CCMI-CHSM) and (ii) different model runs for the same MIPs (HTAPII-CHSR and HTAPII-GCAD, CCMI-CHSM and CCMI-GEOSCCM), and (iii) these were some of the only models that output total VOC emissions, which are better indicators for ozone chemistry than carbon monoxide (Monks et al., 2015). The monthly mean surface ozone data over the study region from these simulations were combined with the monthly mean surface emissions of VOCs and $\mathrm{NO}_{x}$ to generate the plots in Fig. 14. The dots in each panel indicate the locations (in VOC and $\mathrm{NO}_{x}$ space) that the model ozone data samples. As can be seen, there is wide variation in the VOC- $\mathrm{NO}_{x}$ space sampled by the models due to differences in their input emissions, as discussed in Sect. 2.2.

Unlike the ozone isopleths shown in Squire et al. (2015), which focused on grid boxes dominated by isoprene chemistry, the isopleths here generally show a double peak structure, with high ozone at both high and low $\mathrm{NO}_{x}$ and VOC emissions (i.e. the bottom left and top right of each panel). This suggests that this analysis is not connecting in situ produced $\mathrm{O}_{3}$ to the underlying emissions of VOCs and $\mathrm{NO}_{x}$ and shows effects of pollutants from other regions as well. HTAPII-CHSR and CCMI-CHSM have the same chemistry scheme but the different inputs used cause the ozone to respond differently to the $\mathrm{NO}_{x}$ and VOC emissions. The HTAPII models (HTAPII-CHSR and HTAPII-GCAD) have 

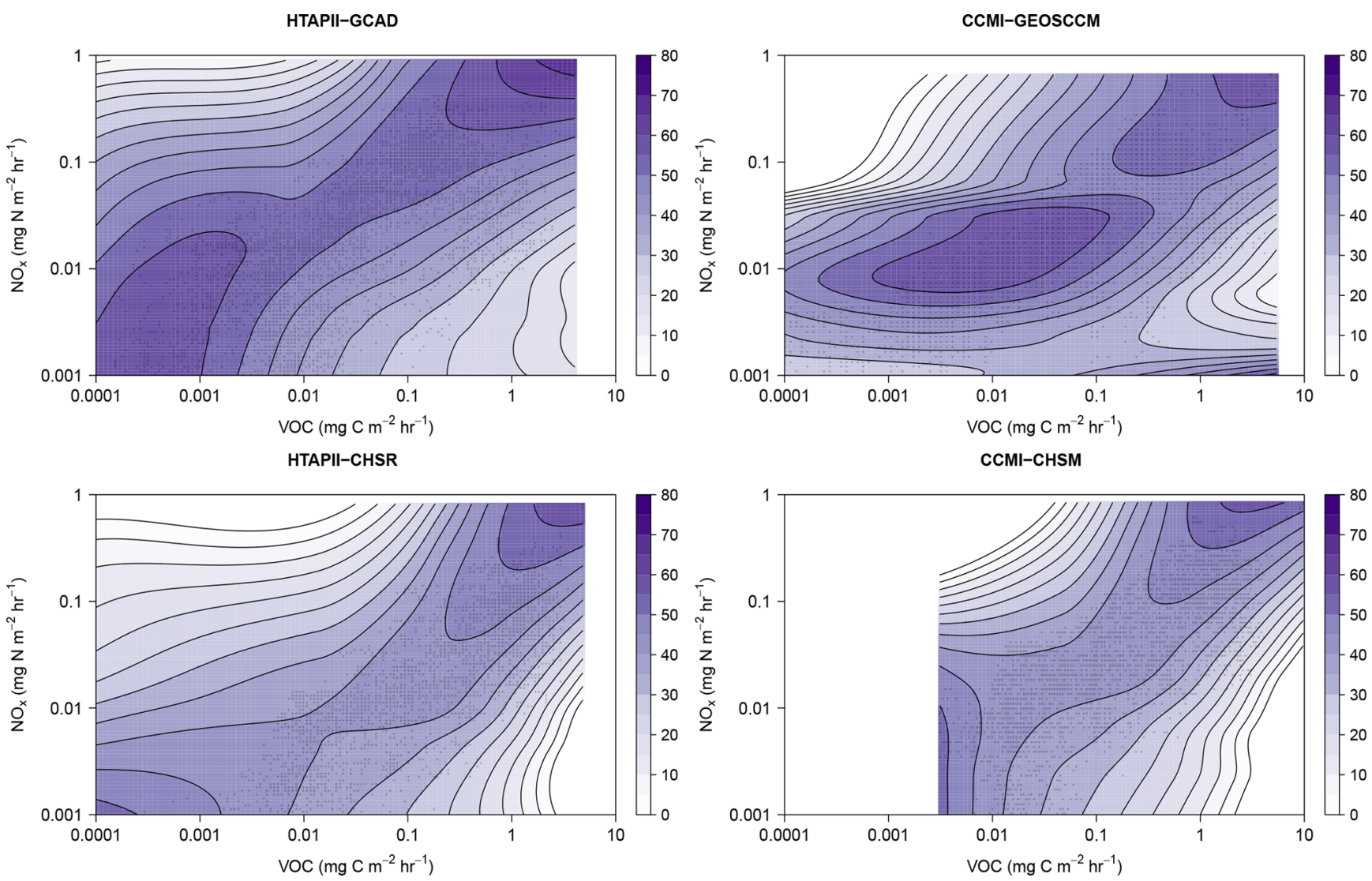

Figure 14. Isopleths of ozone concentration in parts per billion (ppb) as a function of $\mathrm{NO}_{x}$ and VOC emissions over the domain. The dots in each panel indicate the locations (in $\mathrm{VOC}_{\text {and }} \mathrm{NO}_{x}$ space) that the model ozone data samples.

the same anthropogenic emission inputs but the difference in the chemistry scheme used causes the ozone to respond differently to the $\mathrm{NO}_{x}$ and VOC emissions. On similar lines, the CCMI models (CCMI-CHSM and CCMI-GEOSCCM) also give different isopleth patterns.

\section{Conclusions}

In this study, we have systematically assessed differences and similarities in the modelled ozone from eight different models, contributing to the HTAPII and CCMI model intercomparison projects, over the Indian subcontinent. Large inter-model variability is observed in the model-simulated annual average surface. Tropospheric $\mathrm{O}_{3}$ and ozone precursors from these models have been evaluated against a set of ground-based, aircraft and satellite observations over India. Comparison between the model-simulated and ground-based observations of surface ozone show some similarities between the seasonal cycle, except at Chennai. However, models overestimate the ozone mixing ratios at all locations, with CCMI-UKCA giving the highest values of annual average surface ozone.
While a detailed evaluation of why CCMI-UKCA simulates the highest levels of annual mean surface ozone is beyond the scope of this study, we note that further work should be performed to understand the reasons behind this behaviour. Simulations similar to those in Prather et al. (2018) would potentially help shed light on the role of the chemical scheme as a source of bias in the model.

Models underestimate $\mathrm{NO}_{x}$ mixing ratios, except for HTAPII-HDGM at Patiala. $\mathrm{NO}_{2}$ dominates $\mathrm{NO}_{x}$ in the models. Models tend to underestimate CO only at Delhi and Patiala and perform well at the other ground-based stations. It is important to note that the sites considered in this study are categorised as semi-urban and are therefore influenced by local emissions, which are not well represented in global models. Models with coarse-resolution grids are unable to capture the short timescale processes taking place at the local scale and result in the underestimation of surface carbon monoxide and $\mathrm{NO}_{x}$ and the overestimation of ozone, as we have shown in Figs. 3-7. In order to better evaluate global model simulations of surface ozone, we would suggest the need for a network of rural stations measuring ozone and ozone precursors (i.e. $\mathrm{NO}_{x}, \mathrm{CO}, \mathrm{VOCs}$ ), covering different geographical and chemical environments across India. 
Model simulations of total TOC show similar spatial patterns compared to the OMI data over the study domain, but they overestimate the total TOC values, with biases ranging from $16 \%$ to $40 \%$. EOF analysis highlights that more than $70 \%$ of the ozone variation in models is dependent on a single phenomenon, i.e. EOF1.

Comparison with the CARIBIC ozone and $\mathrm{CO}$ profiles indicate that models perform fairly well in the upper troposphere as compared to the lower troposphere. The sparse observations of $\mathrm{CO}$ and $\mathrm{O}_{3}$ profiles limit the evaluation of model ozone and $\mathrm{CO}$ profiles over this region. It is clear from the ozone isopleths that different inputs and chemistry schemes used in these models cause the ozone to respond differently to VOCs and $\mathrm{NO}_{x}$ emissions. Large variation in lightning $\mathrm{NO}_{x}$ emissions is one of the major reasons for the differences in the total $\mathrm{NO}_{x}$ emissions. Further investigation to support this study including the details of chemistry schemes and the simulations of $\mathrm{VOC}, \mathrm{HO}_{2}$ needs to be evaluated within each model. For future chemistry-climate model intercomparisons, we recommend the inclusion of simulations with standardisation of non-anthropogenic emission sources as well as anthropogenic sources in order to be able to diagnose the impact of model chemistry only on tropospheric ozone.

Data availability. The CCMI data used here are held at the Centre for Environmental Data Analysis (CEDA; http://data.ceda.ac.uk/ badc/wcrp-ccmi/data/CCMI-1/, last access: 1 November 2018). For instructions on access to the archive see http://blogs.reading.ac.uk/ ccmi/badc-data-access (IGAC/SPARC Chemistry-Climate Model Initiative, 2018). The HTAPII model data can be downloaded upon request from the AeroCom database (http://www.htap.org/, last access: 1 November 2018.) (TF HTAP, 2018). The SAFAR observational data can be provided upon request to the SAFAR team (safar@tropmet.res.in).

Supplement. The supplement related to this article is available online at: https://doi.org/10.5194/acp-19-6437-2019-supplement.

Author contributions. ZH performed all analysis and led the study, which ATA designed. GB provided the MAPAN data and expert advice on their use. SAN, ZH and ATA led the writing of the paper and all co-authors contributed to reviewing the paper and improving the study. GAF, KS, NLA, SG and DKH all provided data from their global model runs to be analysed and advice on their interpretation.

Competing interests. The authors declare that they have no conflict of interest.

Acknowledgements. The authors acknowledge the Isaac Newton Trust for funding. We thank the System for Air Quality and Weather
Forecasting and Research (SAFAR) project and the Modelling Atmospheric Pollution and Networking (MAPAN) project, Indian Institute of Tropical Meteorology, Pune, India, for the groundbased measurements used in this study. Gerd A. Folberth was supported by the Joint UK BEIS/Defra Met Office Hadley Centre Climate Programme (GA01101) and the European Union's Horizon 2020 Research and Innovation Programme under grant agreement no. 641816 (CRESCENDO). GEOSCCM is supported by the NASA MAP program, and the high-performance computing resources were provided by the NASA Centre for Climate Simulation (NCCS). We thank Stacey M. Frith for helping us access the GEOSCCM output. We also thank Makoto Deushi, Meteorological Research Institute (MRI), Japan, for helping us access the MRI-ESM1r1 simulations and Yanko Davila, Department of Mechanical Engineering, University of Colorado, Boulder, CO, USA, for the GEOSCHEM-ADJOINT simulations for the present study. Daven K. Henze recognises support from NASA HAQAST. UMUKCA-UCAM model integrations were performed using the ARCHER UK National Supercomputing Service and MONSooN system, a collaborative facility supplied under the Joint Weather and Climate Research Programme, which is a strategic partnership between the UK Met Office and the Natural Environment Research Council. We thank CARIBIC partners as well as Lufthansa, especially Lufthansa Technik, for support. We acknowledge the AURA MLS and OMI instruments and algorithm teams for the satellite measurements used in this study. Finally, we would like to thank Narendra Ojha and the second anonymous reviewer for taking the time to review the paper and offer helpful feedback and comments.

This research has been supported by the NERC Atmospheric Pollution and Human Health in an Indian Megacity programme (grant no. NE/P016383/1).

Review statement. This paper was edited by Tim Butler and reviewed by Narendra Ojha and one anonymous referee.

\section{References}

Adachi, Y., Yukimoto, S., Deushi, M., Obata, A., Nakano, H., Tanaka, T. Y., Hosaka, M., Sakami, T., Yoshimura, H., Hirabara, M., Shindo, E., Tsujino, H., Mizuta, R., Yabu, S., Koshiro, T., Ose, T., and Kitoh, A.: Basic performance of a new earth system model of the Meteorological Research Institute, Pap. Meteorol. Geophys., 61, 1-19, https://doi.org/10.2467/mripapers.64.1, 2013.

Ahammed, Y. N., Reddy, R. R., Gopal, K. R., Narasimhulu, K., Basha, D. B., Reddy, L. S. S., and Rao, T. V. R.: Seasonal variation of the surface ozone and its precursor gases during 2001-2003, measured at Anantapur $\left(14.62^{\circ} \mathrm{N}\right)$, a semi-arid site in India, Atmos. Res., 80, 151-164, https://doi.org/10.1016/j.atmosres.2005.07.002, 2006.

Bednarz, E., Maycock, A., Braesicke, P., Telford, P., and Abraham, L.: The role of ozone feedback in modulating the atmospheric response to the solar cycle forcing, EGU General Assembly 2016 , Vienna Austria, 17-22 April 2016, 18, 10660, 2016.

Beig, G., Gunthe, S., and Jadhav, D. B.: Simultaneous measurements of ozone and its precursors on a diurnal scale at 
a semi urban site in India, J. Atmos. Chem., 57, 239-253, https://doi.org/10.1007/s10874-007-9068-8, 2007.

Beig, G., Chate, D. M., Ghude, S. D., Mahajan, A. S., Srinivas, R., Ali, K., Sahu, S. K., Parkhi, N., Surendran, D., and Trimbake, H. R.: Quantifying the effect of air quality control measures during the 2010 Commonwealth Games at Delhi, India, Atmos. Environ., 80, 455-463, https://doi.org/10.1016/j.atmosenv.2013.08.012, 2013.

Bowdalo, D. R., Evans, M. J., and Sofen, E. D.: Spectral analysis of atmospheric composition: application to surface ozone modelmeasurement comparisons, Atmos. Chem. Phys., 16, 82958308, https://doi.org/10.5194/acp-16-8295-2016, 2016.

Brenninkmeijer, C. A. M., Crutzen, P., Boumard, F., Dauer, T., Dix, B., Ebinghaus, R., Filippi, D., Fischer, H., Franke, H., Frieß, U., Heintzenberg, J., Helleis, F., Hermann, M., Kock, H. H., Koeppel, C., Lelieveld, J., Leuenberger, M., Martinsson, B. G., Miemczyk, S., Moret, H. P., Nguyen, H. N., Nyfeler, P., Oram, D., O’Sullivan, D., Penkett, S., Platt, U., Pupek, M., Ramonet, M., Randa, B., Reichelt, M., Rhee, T. S., Rohwer, J., Rosenfeld, K., Scharffe, D., Schlager, H., Schumann, U., Slemr, F., Sprung, D., Stock, P., Thaler, R., Valentino, F., van Velthoven, P., Waibel, A., Wandel, A., Waschitschek, K., Wiedensohler, A., Xueref-Remy, I., Zahn, A., Zech, U., and Ziereis, H.: Civil Aircraft for the regular investigation of the atmosphere based on an instrumented container: The new CARIBIC system, Atmos. Chem. Phys., 7, 4953-4976, https://doi.org/10.5194/acp-7-4953-2007, 2007.

Camalier, L., Cox, W., and Dolwick, P.: The effects of meteorology on ozone in urban areas and their use in assessing ozone trends, Atmos. Environ., 41, 7127-7137, https://doi.org/10.1016/j.atmosenv.2007.04.061, 2007.

Cepeda, J. C. and Colome, D. G.: Benefits of empirical orthogonal functions in pattern recognition applied to vulnerability assessment, IEEE Pow. Ener. Soc. Ge. - Latin America (PES T\&D-LA), Medellin, Colombia, 10-13 September 2014, https://doi.org/10.1109/TDC-LA.2014.6955254, 2014.

Chakraborty, T., Beig, G., Dentener, F. J., and Wild, O.: Atmospheric transport of ozone between Southern and Eastern Asia, Sci. Total Environ., 523, 28-39, https://doi.org/10.1016/j.scitotenv.2015.03.066, 2015.

Cohen, A. J., Brauer, M., Burnett, R., Anderson, H. R., Frostad, J., Estep, K., Balakrishnan, K., Brunekreef, B., Dandona, L., Dandona, R., Feigin, V., Freedman, G., Hubbell, B., Jobling, A., Kan, H., Knibbs, L., Liu, Y., Martin, R., Morawska, L., Pope, C. A., Shin, H., Straif, K., Shaddick, G., Thomas, M., van Dingenen, R., van Donkelaar, A., Vos, T., Murray, C. J. L., and Forouzanfar, M. H.: Estimates and 25-year trends of the global burden of disease attributable to ambient air pollution: an analysis of data from the Global Burden of Diseases Study 2015, Lancet, 389, 1907-1918, https://doi.org/10.1016/S0140-6736(17)30505-6, 2017.

Collins, W. J., Bellouin, N., Doutriaux-Boucher, M., Gedney, N., Halloran, P., Hinton, T., Hughes, J., Jones, C. D., Joshi, M., Liddicoat, S., Martin, G., O'Connor, F., Rae, J., Senior, C., Sitch, S., Totterdell, I., Wiltshire, A., and Woodward, S.: Development and evaluation of an Earth-System model - HadGEM2, Geosci. Model Dev., 4, 1051-1075, https://doi.org/10.5194/gmd-4-10512011, 2011.

David, L. M. and Nair, P. R.: Tropospheric column $\mathrm{O}_{3}$ and $\mathrm{NO}_{2}$ over the Indian region observed by Ozone Monitoring Instrument (OMI): Seasonal changes and long-term trends, Atmos. Envi- ron., 65, 25-39, https://doi.org/10.1016/j.atmosenv.2012.09.033, 2013.

Derwent, R. G., Manning, A. J., Simmonds, P. G., Spain, T. G., and O'Doherty, S.: Analysis and interpretation of 25 years of ozone observations at the Mace Head Atmospheric Research Station on the Atlantic Ocean coast of Ireland from 1987 to 2012, Atmos. Environ., 80, 361-368, https://doi.org/10.1016/j.atmosenv.2013.08.003, 2013.

Fuchs, H., Dubé, W. P., Lerner, B. M., Wagner, N. L., Williams, E. J., and Brown, S. S.: A sensitive and versatile detector for atmospheric $\mathrm{NO}_{2}$ and $\mathrm{NO}_{x}$ based on blue diode laser cavity ring-down spectroscopy, Environ. Sci. Technol., 43, 7831-7836, https://doi.org/10.1021/es902067h, 2009.

Gao, J.: Downscaling Global Spatial Population Projections from Cells, National Center for Atmospheric Research, NCAR Technical Notes NCAR/TN-537 + STR, 2017.

Gaudel, A., Cooper, O. R., Ancellet, G., Barret, B., Boynard, A., Burrows, J. P., Clerbaux, C., Coheur, P.-F., Cuesta, J., Cuevas, E., Doniki, S., Dufour, G., Ebojie, F., Foret, G., Garcia, O., Granados-Muñoz, M. J., Hannigan, J. W., Hase, F., Hassler, B., Huang, G., Leblanc, T., Le Flochmoën, E., Lin, W., Liu, J., Liu, X., Mahieu, E., Mcclure-Begley, A., Neu, J. L., Osman, M., Palm, M., Petetin, H., Petropavlovskikh, I., Querel, R., Rahpoe, N., Rozanov, A., Schultz, M. G., Schwab, J., Siddans, R., Smale, D., Steinbacher, M., Tanimoto, H., Tarasick, D. W., Thouret, V., Thompson, A. M., Trickl, T., Weatherhead, E., Wespes, C., Worden, H. M., Vigouroux, C., Xu, X., Zeng, G., and Ziemke, J.: Tropospheric Ozone Assessment Report: Present-day distribution and trends of tropospheric ozone relevant to climate and global atmospheric chemistry model evaluation, Elem. Sci. Anth., 6, 39, https://doi.org/10.1525/elementa.291, 2018.

Ghude, S. D., Jain, S. L., Arya, B. C., Beig, G., Ahammed, Y. N., Kumar, A., and Tyagi, B.: Ozone in ambient air at a tropical megacity, Delhi: Characteristics, trends and cumulative ozone exposure indices, J. Atmos. Chem., 60, 237-252, https://doi.org/10.1007/s10874-009-9119-4, 2008.

Ghude, S. D., Pfister, G. G., Jena, C., Van Der A, R. J., Emmons, L. K., and Kumar, R.: Satellite constraints of nitrogen oxide $\left(\mathrm{NO}_{x}\right)$ emissions from India based on OMI observations and WRF-Chem simulations, Geophys. Res. Lett., 40, 423-428, https://doi.org/10.1029/2012GL053926, 2013.

Grant, A., Archibald, A. T., Cooke, M. C., and Shallcross, D. E.: Modelling the oxidation of seventeen volatile organic compounds to track yields of $\mathrm{CO}$ and $\mathrm{CO}_{2}$, Atmos. Environ., 44, 3797-3804, https://doi.org/10.1016/j.atmosenv.2010.06.049, 2010.

Health Effects Institute: State of Global Air 2017, Health Effects Institute, available at: http://www.stateofglobalair.org/sites/default/ files/soga-2018-report.pdf, last access: 14 August 2017.

Henze, D. K., Hakami, A., and Seinfeld, J. H.: Development of the adjoint of GEOS-Chem, Atmos. Chem. Phys., 7, 2413-2433, https://doi.org/10.5194/acp-7-2413-2007, 2007.

IGAC/SPARC Chemistry-Climate Model Initiative: BADC data access, available at: http://blogs.reading.ac.uk/ccmi/ badc-data-access, last access: 1 November 2018.

Im, U., Bianconi, R., Solazzo, E., Kioutsioukis, I., Badia, A., Balzarini, A., Baró, R., Bellasio, R., Brunner, D., Chemel, C., Curci, G., Flemming, J., Forkel, R., Giordano, L., JiménezGuerrero, P., Hirtl, M., Hodzic, A., Honzak, L., Jorba, O., Knote, 
C., Kuenen, J. J. P., Makar, P. A., Manders-Groot, A., Neal, L., Pérez, J. L., Pirovano, G., Pouliot, G., San Jose, R., Savage, N., Schroder, W., Sokhi, R. S., Syrakov, D., Torian, A., Tuccella, P., Werhahn, J., Wolke, R., Yahya, K., Zabkar, R., Zhang, Y., Zhang, J., Hogrefe, C., and Galmarini, S.: Evaluation of operational on-line-coupled regional air quality models over Europe and North America in the context of AQMEII phase 2 - Part I: Ozone, Atmos. Environ., 115, 404-420, https://doi.org/10.1016/j.atmosenv.2014.09.042, 2015.

Jain, S. L., Arya, B. C., Kumar, A., Ghude, S. D., and Kulkarni, P. S.: Observational study of surface ozone at New Delhi, India, Int. J. Remote Sens., 26, 3515-3524, https://doi.org/10.1080/01431160500076616, 2005.

Jenkin, M. E. and Clemitshaw, K. C.: Ozone and other secondary photochemical pollutants: chemical processes governing their formation in the planetary boundary layer, chap. 11, Dev. Environ. Sci., 1, 285-338, https://doi.org/10.1016/S14748177(02)80014-6, 2002.

Jones, B. and O'Neill, B. C.: Spatially explicit global population scenarios consistent with the Shared Socioeconomic Pathways, Environ. Res. Lett., 11, 084003, https://doi.org/10.1088/17489326/11/8/084003, 2016.

Keeble, J., Bednarz, E. M., Banerjee, A., Abraham, N. L., Harris, N. R. P., Maycock, A. C., and Pyle, J. A.: Diagnosing the radiative and chemical contributions to future changes in tropical column ozone with the UM-UKCA chemistry-climate model, Atmos. Chem. Phys., 17, 13801-13818, https://doi.org/10.5194/acp-1713801-2017, 2017.

Koffi, B., Dentener, F., Janssens-Maenhout, G., Guizzardi, D., Crippa, M., Diehl, T., Galmarini, S., and Solazzo, E.: Hemispheric Transport of Air Pollution (HTAP): Specification of the HTAP2 experiments: ensuring harmonized modelling, Publications Office of the European Union, https://doi.org/10.2788/725244. 2016.

Lal, D. M., Ghude, S. D., Patil, S. D., Kulkarni, S. H., Jena, C., Tiwari, S., and Srivastava, M. K.: Tropospheric ozone and aerosol long-term trends over the IndoGangetic Plain (IGP), India, Atmos. Res., 116, 82-92, https://doi.org/10.1016/j.atmosres.2012.02.014, 2012.

Malley, C. S., Henze, D. K., Kuylenstierna, J. C. I., Vallack, H. W., Davila, Y., Anenberg, S. C., Turner, M. C., and Ashmore, M. R.: Updated global estimates of respiratory mortality in adults $\geq 30$ years of age attributable to long-term ozone exposure, Environ. Health Perspect., 125, 1-9, https://doi.org/10.1289/EHP1390, 2017

Monks, P. S., Archibald, A. T., Colette, A., Cooper, O., Coyle, M., Derwent, R., Fowler, D., Granier, C., Law, K. S., Mills, G. E., Stevenson, D. S., Tarasova, O., Thouret, V., von Schneidemesser, E., Sommariva, R., Wild, O., and Williams, M. L.: Tropospheric ozone and its precursors from the urban to the global scale from air quality to short-lived climate forcer, Atmos. Chem. Phys., 15, 8889-8973, https://doi.org/10.5194/acp-15-8889-2015, 2015.

Morgenstern, O., Hegglin, M. I., Rozanov, E., O’Connor, F. M., Abraham, N. L., Akiyoshi, H., Archibald, A. T., Bekki, S., Butchart, N., Chipperfield, M. P., Deushi, M., Dhomse, S. S., Garcia, R. R., Hardiman, S. C., Horowitz, L. W., Jöckel, P., Josse, B., Kinnison, D., Lin, M., Mancini, E., Manyin, M. E., Marchand, M., Marécal, V., Michou, M., Oman, L. D., Pitari, G., Plummer, D. A., Revell, L. E., Saint-Martin, D., Schofield,
R., Stenke, A., Stone, K., Sudo, K., Tanaka, T. Y., Tilmes, S., Yamashita, Y., Yoshida, K., and Zeng, G.: Review of the global models used within phase 1 of the Chemistry-Climate Model Initiative (CCMI), Geosci. Model Dev., 10, 639-671, https://doi.org/10.5194/gmd-10-639-2017, 2017.

Nair, A., Mohanty, U. C., Robertson, A. W., Panda, T. C., Luo, J. J., and Yamagata, T.: An analytical study of hindcasts from general circulation models for Indian summer monsoon rainfall, Meteorol. Appl., 21, 695-707, https://doi.org/10.1002/met.1395, 2014.

Naja, M., Lal, S., and Chand, D.: Diurnal and seasonal variabilities in surface ozone at a high altitude site Mt Abu $\left(24.6^{\circ} \mathrm{N}\right.$, $72.7^{\circ}$ E, $1680 \mathrm{~m}$ a.s.1.) in India, Atmos. Environ., 37, 4205-4215, https://doi.org/10.1016/S1352-2310(03)00565-X, 2003.

O'Connor, F. M., Johnson, C. E., Morgenstern, O., Abraham, N. L., Braesicke, P., Dalvi, M., Folberth, G. A., Sanderson, M. G., Telford, P. J., Voulgarakis, A., Young, P. J., Zeng, G., Collins, W. J., and Pyle, J. A.: Evaluation of the new UKCA climatecomposition model - Part 2: The Troposphere, Geosci. Model Dev., 7, 41-91, https://doi.org/10.5194/gmd-7-41-2014, 2014.

Ojha, N., Pozzer, A., Rauthe-Schöch, A., Baker, A. K., Yoon, J., Brenninkmeijer, C. A. M., and Lelieveld, J.: Ozone and carbon monoxide over India during the summer monsoon: regional emissions and transport, Atmos. Chem. Phys., 16, 3013-3032, https://doi.org/10.5194/acp-16-3013-2016, 2016.

Oman, L. D., Ziemke, J. R., Douglass, A. R., Waugh, D. W., Lang, C., Rodriguez, J. M., and Nielsen, J. E.: The response of tropical tropospheric ozone to ENSO, Geophys. Res. Lett., L13706, https://doi.org/10.1029/2011GL047865, 2011.

Parrish, D. D., Lamarque, J. F., Naik, V., Horowitz, L., Shindell, D. T., Staehelin, J., Derwent, R., Cooper, O. R., Tanimoto, H., Volz-Thomas, A., Gilge, S., Scheel, H. E., Steinbacher, M., and Fröhlich, M.: Long-term changes in lower tropospheric baseline ozone concentrations: Comparing chemistry-climate models and observations at northern midlatitudes, J. Geophys. Res., 119, 5719-5736, https://doi.org/10.1002/2013JD021435, 2014.

Rienecker, M. M., Suarez, M. J., Todling, R., Bacmeister, J., Takacs, L., Liu, H. C., Gu, W., Sienkiewicz, M., Koster, R. D., and Gelaro, R.: The GEOS-5 Data Assimilation SystemDocumentation of Versions 5.0.1, 5.1.0, and 5.2.0, Technical Report Series on Global Modeling and Data Assimilation, NASA/TM-2008-104606, Vol. 27, 2008.

Scharffe, D., Slemr, F., Brenninkmeijer, C. A. M., and Zahn, A.: Carbon monoxide measurements onboard the CARIBIC passenger aircraft using UV resonance fluorescence, Atmos. Meas. Tech., 5, 1753-1760, https://doi.org/10.5194/amt-5-1753-2012, 2012.

Schuck, T. J., Brenninkmeijer, C. A. M., Baker, A. K., Slemr, F., von Velthoven, P. F. J., and Zahn, A.: Greenhouse gas relationships in the Indian summer monsoon plume measured by the CARIBIC passenger aircraft, Atmos. Chem. Phys., 10, 3965 3984, https://doi.org/10.5194/acp-10-3965-2010, 2010.

Sinha, B., Singh Sangwan, K., Maurya, Y., Kumar, V., Sarkar, C., Chandra, B. P., and Sinha, V.: Assessment of crop yield losses in Punjab and Haryana using 2 years of continuous in situ ozone measurements, Atmos. Chem. Phys., 15, 9555-9576, https://doi.org/10.5194/acp-15-9555-2015, 2015.

Solazzo, E., Bianconi, R., Hogrefe, C., Curci, G., Tuccella, P. Alyuz, U., Balzarini, A., Baró, R., Bellasio, R., Bieser, J., Brandt, J., Christensen, J. H., Colette, A., Francis, X., Fraser, A., Vi- 
vanco, M. G., Jiménez-Guerrero, P., Im, U., Manders, A., Nopmongcol, U., Kitwiroon, N., Pirovano, G., Pozzoli, L., Prank, M., Sokhi, R. S., Unal, A., Yarwood, G., and Galmarini, S.: Evaluation and error apportionment of an ensemble of atmospheric chemistry transport modeling systems: multivariable temporal and spatial breakdown, Atmos. Chem. Phys., 17, 3001-3054, https://doi.org/10.5194/acp-17-3001-2017, 2017.

Squire, O. J., Archibald, A. T., Griffiths, P. T., Jenkin, M. E., Smith, D., and Pyle, J. A.: Influence of isoprene chemical mechanism on modelled changes in tropospheric ozone due to climate and land use over the 21st century, Atmos. Chem. Phys., 15, 5123-5143, https://doi.org/10.5194/acp-15-5123-2015, 2015.

Stevenson, D. S., Young, P. J., Naik, V., Lamarque, J.-F., Shindell, D. T., Voulgarakis, A., Skeie, R. B., Dalsoren, S. B., Myhre, G., Berntsen, T. K., Folberth, G. A., Rumbold, S. T., Collins, W. J., MacKenzie, I. A., Doherty, R. M., Zeng, G., van Noije, T. P. C., Strunk, A., Bergmann, D., Cameron-Smith, P., Plummer, D. A., Strode, S. A., Horowitz, L., Lee, Y. H., Szopa, S., Sudo, K., Nagashima, T., Josse, B., Cionni, I., Righi, M., Eyring, V., Conley, A., Bowman, K. W., Wild, O., and Archibald, A.: Tropospheric ozone changes, radiative forcing and attribution to emissions in the Atmospheric Chemistry and Climate Model Intercomparison Project (ACCMIP), Atmos. Chem. Phys., 13, 3063-3085, https://doi.org/10.5194/acp-13-3063-2013, 2013.

Stock, Z. S., Russo, M. R., and Pyle, J. A.: Representing ozone extremes in European megacities: the importance of resolution in a global chemistry climate model, Atmos. Chem. Phys., 14, 3899-3912, https://doi.org/10.5194/acp-14-3899-2014, 2014.

Sudo, K., Takahashi, M., Kurokawa, J. I., and Akimoto, H.: CHASER: A global chemical model of the troposphere 1. Model description, J. Geophys. Res. Atmos., 107, 4339, https://doi.org/10.1029/2001JD001113, 2002.

Surendran, D. E., Ghude, S. D., Beig, G., Emmons, L. K., Jena, C., Kumar, R., Pfister, G. G., and Chate, D. M.: Air quality simulation over South Asia using Hemispheric Transport of Air Pollution version-2 (HTAP-v2) emission inventory and Model for Ozone and Related chemical Tracers (MOZART-4), Atmos. Environ., 122, 357-372, https://doi.org/10.1016/j.atmosenv.2015.08.023, 2015.

Task Force on Hemispheric Transport of Air Pollution (TF HTAP): HTAPII model data, available at: http://www.htap.org/, last access: 1 November 2018.

Tilmes, S., Lamarque, J.-F., Emmons, L. K., Kinnison, D. E., Ma, P.-L., Liu, X., Ghan, S., Bardeen, C., Arnold, S., Deeter, M., Vitt, F., Ryerson, T., Elkins, J. W., Moore, F., Spackman, J. R., and Val Martin, M.: Description and evaluation of tropospheric chemistry and aerosols in the Community Earth System Model (CESM1.2), Geosci. Model Dev., 8, 1395-1426, https://doi.org/10.5194/gmd8-1395-2015, 2015.

Voulgarakis, A., Wild, O., Savage, N. H., Carver, G. D., and Pyle, J. A.: Clouds, photolysis and regional tropospheric ozone budgets, Atmos. Chem. Phys., 9, 8235-8246, https://doi.org/10.5194/acp9-8235-2009, 2009.
Waters, J. W., Froidevaux, L., Harwood, R. S., Jarnot, R. F., Pickett, H. M., Read, W. G., Siegel, P. H., Cofield, R. E., Filipiak, M. J., Flower, D. A., Holden, J. R., Lau, G. K., Livesey, N. J., Manney, G. L., Pumphrey, H. C., Santee, M. L., Wu, D. L., Cuddy, D. T., Lay, R. R., Loo, M. S., Perun, V. S., Schwartz, M. J., Stek, P. C., Thurstans, R. P., Boyles, M. A., Chandra, K. M., Chavez, M. C., Chen, G. S., Chudasama, B. V., Dodge, R., Fuller, R. A., Girard, M. A., Jiang, J. H., Jiang, Y., Knosp, B. W., Labelle, R. C., Lam, J. C., Lee, K. A., Miller, D., Oswald, J. E., Patel, N. C., Pukala, D. M., Quintero, O., Scaff, D. M., Van Snyder, W., Tope, M. C., Wagner, P. A., and Walch, M. J.: The Earth Observing System Microwave Limb Sounder (EOS MLS) on the aura satellite, IEEE Trans. Geosci. Remote, 44, 1075-1092, https://doi.org/10.1109/TGRS.2006.873771, 2006.

Winer, A. M., Peters, J. W., Smith, J. P., and Pitts, J. N.: Response of commercial chemiluminescent $\mathrm{NO}-\mathrm{NO}_{2}$ analyzers to other nitrogen-containing compounds, Environ. Sci. Technol., 8, 1118-1121, https://doi.org/10.1021/es60098a004, 1974.

Yadav, R., Sahu, L. K., Jaaffrey, S. N. A., and Beig, G.: Temporal variation of Particulate Matter (PM) and potential sources at an urban site of Udaipur in Western India, Aerosol Air Qual. Res., 14, 1613-1629, https://doi.org/10.4209/aaqr.2013.10.0310, 2014.

Yadav, R., Sahu, L. K., Beig, G., and Jaaffrey, S. N. A.: Role of long-range transport and local meteorology in seasonal variation of surface ozone and its precursors at an urban site in India, Atmos. Res., 176-177, 96-107, https://doi.org/10.1016/j.atmosres.2016.02.018, 2016.

Young, P. J., Archibald, A. T., Bowman, K. W., Lamarque, J.-F., Naik, V., Stevenson, D. S., Tilmes, S., Voulgarakis, A., Wild, O., Bergmann, D., Cameron-Smith, P., Cionni, I., Collins, W. J., Dalsøren, S. B., Doherty, R. M., Eyring, V., Faluvegi, G., Horowitz, L. W., Josse, B., Lee, Y. H., MacKenzie, I. A., Nagashima, T., Plummer, D. A., Righi, M., Rumbold, S. T., Skeie, R. B., Shindell, D. T., Strode, S. A., Sudo, K., Szopa, S., and Zeng, G.: Preindustrial to end 21 st century projections of tropospheric ozone from the Atmospheric Chemistry and Climate Model Intercomparison Project (ACCMIP), Atmos. Chem. Phys., 13, 2063 2090, https://doi.org/10.5194/acp-13-2063-2013, 2013.

Zahn, A., Weppner, J., Widmann, H., Schlote-Holubek, K., Burger, B., Kühner, T., and Franke, H.: A fast and precise chemiluminescence ozone detector for eddy flux and airborne application, Atmos. Meas. Tech., 5, 363-375, https://doi.org/10.5194/amt-5363-2012, 2012.

Ziemke, J. R., Chandra, S., Labow, G. J., Bhartia, P. K., Froidevaux, L., and Witte, J. C.: A global climatology of tropospheric and stratospheric ozone derived from Aura OMI and MLS measurements, Atmos. Chem. Phys., 11, 9237-9251, https://doi.org/10.5194/acp-11-9237-2011, 2011. 